\title{
DNA-Dependent Protein Kinase Catalytic Subunit: The Sensor for DNA Double-Strand Breaks Structurally and Functionally Related to Ataxia Telangiectasia Mutated
}

\author{
Yoshihisa Matsumoto *, Anie Day D. C. Asa, Chaity Modak and Mikio Shimada \\ Laboratory for Zero-Carbon Energy, Institute of Innovative Research, Tokyo Institute of Technology, \\ Tokyo 152-8550, Japan; asa.a.aa@m.titech.ac.jp (A.D.D.C.A.); modak.c.aa@m.titech.ac.jp (C.M.); \\ mshimada@zc.iir.titech.ac.jp (M.S.) \\ * Correspondence: yoshim@zc.iir.titech.ac.jp; Tel.: +81-3-5734-2273
}

check for

updates

Citation: Matsumoto, Y.; Asa, A.D.D.C.; Modak, C.; Shimada, M. DNA-Dependent Protein Kinase Catalytic Subunit: The Sensor for DNA Double-Strand Breaks Structurally and Functionally Related to Ataxia Telangiectasia Mutated. Genes 2021, 12, 1143. https: / /doi.org/ 10.3390 /genes12081143

Academic Editors: Junya Kobayashi and Qiu-Mei Zhang-Akiyama

Received: 4 July 2021

Accepted: 22 July 2021

Published: 27 July 2021

Publisher's Note: MDPI stays neutral with regard to jurisdictional claims in published maps and institutional affiliations.

Copyright: (c) 2021 by the authors. Licensee MDPI, Basel, Switzerland. This article is an open access article distributed under the terms and conditions of the Creative Commons Attribution (CC BY) license (https:/ / creativecommons.org/licenses/by/ $4.0 /)$.

\begin{abstract}
The DNA-dependent protein kinase (DNA-PK) is composed of a DNA-dependent protein kinase catalytic subunit (DNA-PKcs) and Ku70/Ku80 heterodimer. DNA-PK is thought to act as the "sensor" for DNA double-stranded breaks (DSB), which are considered the most deleterious type of DNA damage. In particular, DNA-PKcs and Ku are shown to be essential for DSB repair through nonhomologous end joining (NHEJ). The phenotypes of animals and human individuals with defective DNA-PKcs or Ku functions indicate their essential roles in these developments, especially in neuronal and immune systems. DNA-PKcs are structurally related to Ataxia-telangiectasia mutated (ATM), which is also implicated in the cellular responses to DSBs. DNA-PKcs and ATM constitute the phosphatidylinositol 3-kinase-like kinases (PIKKs) family with several other molecules. Here, we review the accumulated knowledge on the functions of DNA-PKcs, mainly based on the phenotypes of DNA-PKcs-deficient cells in animals and human individuals, and also discuss its relationship with ATM in the maintenance of genomic stability.
\end{abstract}

Keywords: DNA-dependent protein kinase (DNA-PK); DNA-dependent protein kinase catalytic subunit (DNA-PKcs); Ku; Ataxia-telangiectasia mutated (ATM); protein kinase; phosphatidylinositol 3-kinase-like kinase (PIKK); DNA double-stranded break (DSB); DNA damage response

\section{DNA-PKcs as a Family Member of ATM \\ 1.1. DNA-PK and DNA-PKCS}

The first observation of DNA-dependent protein kinase (DNA-PK) activity dates back to 1985. Walker et al. showed that double-stranded DNA (dsDNA), but not single-stranded DNA or RNA, induced the phosphorylation of multiple proteins, including Heat-shock protein 90 (Hsp90), in a wide variety of eukaryotic cells of human, rabbit, frog and sea urchin origin [1]. Carter et al. and Lees-Miller et al. purified this enzymatic activity from the nuclear extract of human cervical carcinoma HeLa cells and found it to be associated with a 300-350-kDa polypeptide, which is now known as the DNA-dependent protein kinase catalytic subunit (DNA-PKcs) [2,3].

Lees-Miller et al. noticed that the two polypeptides that can be phosphorylated by DNA-PK were copurified in later steps of purification and identified them as the $\mathrm{Ku} 70 / \mathrm{Ku} 80$ heterodimer (hereafter referred to as $\mathrm{Ku}$, simply) [3]. Dynan and colleagues purified a transcription template-associated kinase, which phosphorylates heptapeptide repeats in the C-terminal domain of the largest subunit of RNA polymerase II, and showed that it consists of two components, i.e., a 300-350-kDa polypeptide and $\mathrm{Ku}$ [4]. Jackson and colleagues showed that DNA-PK binds to and requires the end of dsDNA for activity [5]. They demonstrated that $\mathrm{Ku}$ is an essential component of DNA-PK, mediating the binding of DNA-PKcs to the dsDNA end [5].

The $\mathrm{Ku}$ protein was initially identified by Mimori et al. as the antigen of the autoantibody in a patient of an autoimmune disease, polymyositis-scleroderma overlap [6]. 
Subsequent studies showed that the $\mathrm{Ku}$ protein consists of two polypeptides of $70 \mathrm{kDa}$ and $80 \mathrm{kDa}$, which are termed $\mathrm{Ku} 70$ and Ku80 (also termed Ku86), respectively [7], and binds to the end of double-stranded DNA without a particular preference in the nucleotide sequences [8]. Later, X-ray crystallography revealed that $\mathrm{Ku} 70$ and $\mathrm{Ku} 80$ form a ringshaped structure that can encircle DNA, giving a plausible explanation for how Ku binds specifically to the DNA end [9].

The nature of DNA-PK suggests its potential as a "sensor" for DSB. In 1995, Blunt et al. [10], Kirchgessner et al. [11] and Peterson et al. [12] showed that DNA-PKcs are inactivated in severe combined immunodeficiency (SCID) mice. SCID mice were initially established by Bosma et al. in 1983 [13]. SCID mice are defective in the V(D)J recombination of immunoglobulin and T-cell receptor genes (see below and Appendix A) and, as a result, lack B-cell- and T-cell-mediated immunity [14,15]. Cells from SCID mice are sensitive to IR due to a reduced ability in DNA double-stranded break (DSB) repair [16]. In addition, Lees-Miller et al. reported the absence of DNA-PKcs in M059J, which was established from a human malignant glioma specimen, showing radiosensitivity and defective DSB repair [17]. In the year before, Taccioli et al. [18] and Smider et al. [19] showed that Ku80 is inactivated in IR-sensitive and V(D)J recombination-defective hamster cells, such as $x r s-5$, $\mathrm{XR}-\mathrm{V} 15 \mathrm{~B}$ and $s x i-3$. These discoveries indicated that DNA-PKcs and $\mathrm{Ku}$ are essential for DSB repair and $\mathrm{V}(\mathrm{D}) \mathrm{J}$ recombination. This historical perspectives have been reviewed more in detail elsewhere [20].

\subsection{DNA-PKCS and ATM}

The molecular cloning of cDNA-encoding DNA-PKcs was achieved in 1995 and revealed its extremely large size, i.e., 4128 amino acids, which was even larger than expected before [21]. Another surprise was its similarity to Ataxia-telangiectasia mutated (ATM), the gene responsible for ataxia-telangiectasia (AT), which was reported shortly before (Figure 1a) [22]. AT is an autosomal recessive human genetic disorder that shows pleiotropic effects, including defective locomotive regulation (ataxia), the enlargement of capillaries (telangiectasia), immunodeficiency, infertility and an increased risk of cancer. Cells from AT patients exhibit a high sensitivity to IR, showing "radioresistant DNA synthesis", which is an indicative of defective cell cycle checkpoints (especially in the G1/S- and S-phase checkpoints). The primary structure of ATM showed a similarity to phosphatidylinositol 3-kinase [22]. It raised the question of the role of lipid phosphorylation in cell cycle checkpoints, if any. Simultaneously, several genes implicated in cell cycle checkpoint and/or telomere maintenance, i.e., Mei-41 [23] in Drosophila melanogaster and TEL1 [24,25] and MEC1 [26] in Saccharomyces cerevisiae, were found to be structurally related to ATM. Subsequently, ATM- and Rad3-related ATR (also termed FRAP-associated protein-1, FRP1) was found in humans $[27,28]$. ATM and ATR are human orthologs of Saccharomyces cerevisiae TEL1 and MEC1, respectively.

These molecules comprise a family of protein kinases termed phosphatidylinositol 3-kinase-related kinases (PIKKs). In addition to DNA-PKcs, ATM and ATR, three other members of the PIKK family have been identified in humans (Figure 1a). Suppressor of morphological defects on genitalia-1 (SMG-1) is involved in the nonsense-mediated decay of mRNA [29,30]. Mammalian Target of rapamycin (mTOR, also termed FKBP12rapamycin-associated protein, FRAP, and Rapamycin and FKBP12-target, RAFT) regulates cell growth and survival, sensing amino acids and growth factors [31,32]. Transformation/transcription domain-associated protein (TRRAP) is involved in chromatin modification and remodeling and, interestingly, lacks catalytic activity [33]. In addition to the kinase catalytic domain, these molecules show structural similarity in the FAT (FRAP, ATM and TRRAP); PRD (PIKK-regulatory domain) and FATC (FAT C-terminal) domains. They also have less-conserved HEAT (Huntingtin, Elongation factor 3, Protein phosphatase 2A and TOR1) repeats. 


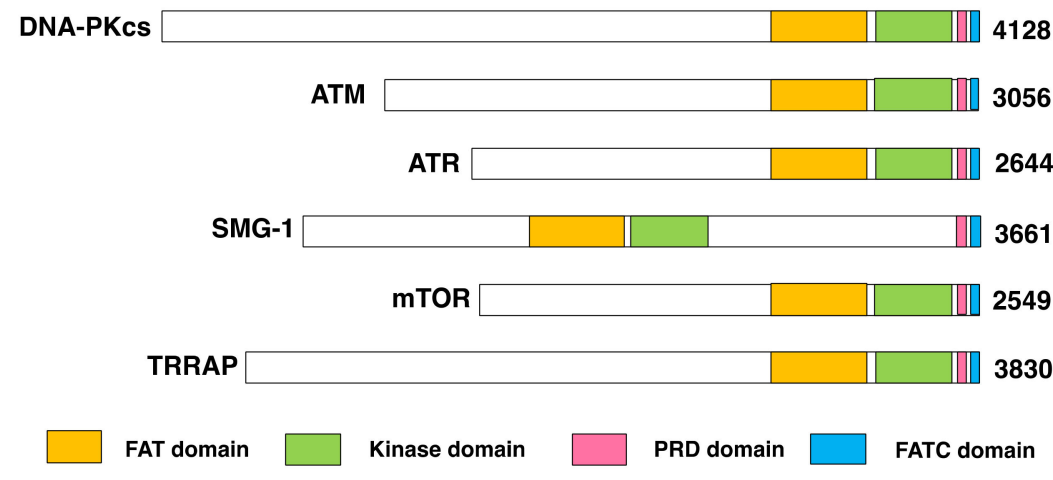

(a)

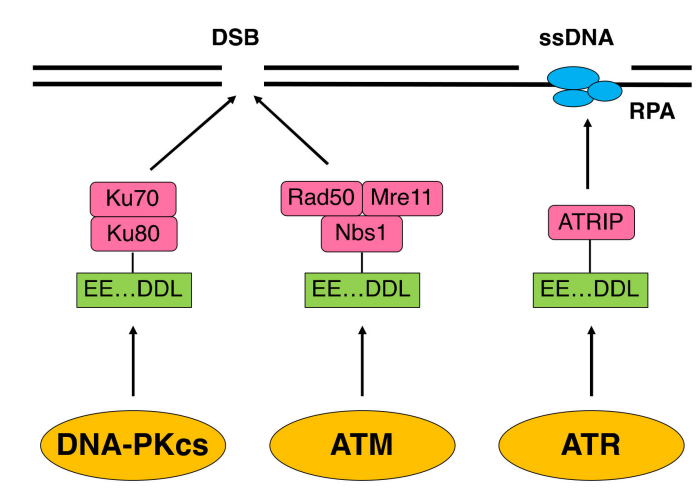

(b)

Figure 1. The similarity of DNA-PKcs to ATM and other PIKKs. (a) The architecture of DNA-PKcs, ATM and other PIKKs. FAT: FRAP-ATM-TRRAP, PRD: PIKK-regulatory and FATC: FAT C-terminal. (b) The mechanisms of the recruitment of DNA-PKcs, ATM and ATR to DSB and ssDNA.

Without the abundant knowledge on DNA-PKcs, these molecules might have been assumed to be lipid kinases rather than protein kinases. However, since DNA-PK is known as an unambiguous protein kinase, these molecules were presumed to be protein kinases, probably sharing similar properties with DNA-PK. It was known that DNA-PK preferentially phosphorylates serines or threonines, followed by glutamines (SQ/TQ motif), including Ser15 of p53 [34,35]. Subsequently, it was shown that ATM and ATR were capable of phosphorylating Ser15 of p53 [36,37]. Thus, SQ/TQ motifs are considered the consensus sequences for ATM and ATR, as well as DNA-PKcs. Furthermore, it was shown that ATM rather than DNA-PKcs are mainly responsible for the phosphorylation of Ser15 of p53 in cellulo in response to DNA damage $[36,37]$. However, these studies also noted a difference in the biochemical property: where DNA-PKcs require $\mathrm{Mg}^{2+}$ for activity, ATM and ATR require $\mathrm{Mn}^{2+}[36,37]$.

While DNA-PK requires $\mathrm{Ku}$ for DNA binding and activation, ATM requires the Mre11Rad50-Nbs1 (MRN) complex [38,39]. ATR binds to ssDNA via Replication protein A (RPA) and ATR-interacting protein (ATRIP) [40]. In the C-termini of Ku80, Nbs1 and ATRIP, there are similar amino acid sequences $\left(\mathrm{EEX}_{3-4} \mathrm{DDL}\right.$, where $\mathrm{X}$ represents any amino acid), which are required for the recruitment of DNA-PKcs, ATM and ATR, respectively [41].

DNA-PKcs and ATM were implicated in the DNA damage response, especially for DSBs. Their similarities in structure and properties raise the question of what the overlapping function(s) and nonoverlapping function(s) between the two molecules is/are. As described above, the defects in DSB repair and V(D)J recombination manifested in DNAPKcs-deficient cells. On the other hand, the defects in cell cycle checkpoints were manifested in cells from AT patients. Hence, it seems that DNA-PK is mainly involved in DSB repair and $\mathrm{V}(\mathrm{D}) \mathrm{J}$ recombination, whereas ATM is mainly involved in cell cycle checkpoints.

\section{Function and Role of DNA-PKcs}

\subsection{DNA-PKcs in Nonhomologous End Joining}

There are two pathways to repair DSBs, which are evolutionally conserved throughout eukaryotes: homologous recombination (HR) and nonhomologous end joining (NHEJ) [42]. HR uses a homologous or identical sequence as the template to reconstitute the DNA sequence around DSB. On the other hand, NHEJ joins two DNA ends in the close vicinity with minimally required modifications (termed processing). Hence, NHEJ may occasionally incur errors, such as nucleotide deletions or insertions at the junction, or ligation with an incorrect partner, leading to chromosomal aberrations such as deletions, inversions, or translocations. Hence, HR is generally considered more accurate than NHEJ. However, $\mathrm{HR}$ requires the sister chromatids in vertebrates and is, therefore, restricted in the late $S$ and G2 phases, whereas the majority of cells are in the G0 and G1 phases. Even in the 
G2 phase, approximately $80 \%$ of DSBs are thought to be repaired via NHEJ in human cells [42]. Moreover, as only a small portion of the genome ( $1 \%$ or less) in vertebrates encodes protein [43], the insertion or deletion of a small number of nucleotides can be tolerated. Thus, NHEJ is thought to have prominent importance, especially in vertebrates, including humans. In addition, NHEJ is also involved in V(D)J recombination [42].

Throughout the 1970s and 1980s, a number of ionizing radiation (IR)-sensitive mutants were isolated from rodent cells. These were classified into 11 complementation groups, and the gene complementing the IR sensitivity of each group was named XRCC1-XRCC11, respectively, where XRCC stands for "X-ray cross-complementing" [44]. The cells that were classified into groups 4, 5 and 7 showed similar characteristics, i.e., the defects in rejoining of IR-induced DSBs and V(D)J recombination [44]. DNA-PKcs and Ku80 correspond to XRCC7 and XRCC5, respectively. XRCC4, which is absent in IR-sensitive and V(D)J recombination defective cells, i.e., hamster XR-1, was identified in 1995 by Li et al. [45]. Subsequently, XRCC4 was shown to be associated with DNA ligase IV (LIG4) and essential for the function and stability of LIG4 [46,47]. Mutations in the LIG4 gene were found in an X-ray-sensitive mutant derived from murine mammary carcinoma cells [48] and in a cell line established from a radiosensitive leukemia patient [49]. Based on these, LIG4 is thought to catalyze the ligation of two DNA ends to complete NHEJ. In 2001, Artemis was found as the gene mutated in human radiosensitive-SCID (RS-SCID) patients [50]. Subsequently, Artemis was shown to be capable of opening a hairpin structure, which appears at the coding ends (Appendix A), and processing overhangs, which result from the hairpin opening [51]. Moreover, DNA-PKcs were shown to form a complex with Artemis in vitro and in vivo and, also, to regulate the above activities of Artemis through phosphorylation in vitro [51]. In 2006, XRCC4-like factor (XLF), which is also known as Cernunnos, was identified as an XRCC4-interacting protein in a two-hybrid screening and, simultaneously, as the gene mutated in human RS-SCID patients with microcephaly $[52,53]$. XLF also showed a similarity to XRCC4 in the predicted 3D structure and is thought to be a paralog of XRCC4 $[53,54]$. XLF was shown to stimulate LIG4 activity for mismatched or noncompatible ends $[55,56]$ and, also, to form filaments with XRCC4, which may have some role in aligning or bridging two DNA ends [57-60]. In 2015, Paralog of XRCC4 and XLF (PAXX, also termed XLS for XRCC4-like small molecule) was identified simultaneously by three groups [61-63]. PAXX was shown to stabilize the binding of $\mathrm{Ku}$ to DSBs and the assembly of the NHEJ complex therein [61-63].

Figure 2 illustrates a simplified diagram of DSB repair through NHEJ. It should be noted that NHEJ is much more sophisticated, involving many other processing enzymes and chromatin remodelers [20,42], but DNA-PKcs, Ku and the other above-mentioned "core" NHEJ factors are illustrated here. DNA-PKcs are thought to be involved in the recognition of DSBs with $\mathrm{Ku}$ and orchestrate the subsequent steps of NHEJ. The kinase activity of DNA-PKcs is considered essential, because it was shown that the catalytically inactive forms of DNA-PKcs were not sufficient to restore the normal radiosensitivity and $\mathrm{V}(\mathrm{D}) \mathrm{J}$ recombination ability in DNA-PKcs-deficient cells [64,65]. However, the target(s) and role(s) of phosphorylation in NHEJ remain to be clarified, as discussed elsewhere [20].

\subsection{Cells Deficient for DNA-PKcs: Role in DSB Repair and V(D)J Recombination}

Table 1 summarizes the DNA-PKcs-deficient cells and their characteristics. In addition to murine scid and human M059J, several mouse and hamster cell lines, which were isolated as IR-sensitive mutants, turned out to be deficient in DNA-PKcs. Furthermore, several DNA-PKcs-deficient cell lines were engineered by gene targeting or, more recently, genome editing. Almost all of them showed an increased sensitivity toward ionizing radiation and drugs, like etoposide and bleomycin, which induce DSBs. A reduced ability in DSB repair of these cells was demonstrated by pulse-field gel electrophoresis, mainly in the 1990s, and, thereafter, by the foci of DSB markers like $\gamma-\mathrm{H} 2 \mathrm{AX}$ and 53BP1. These results indicate the essential roles of DNA-PKcs in DSB repair. 


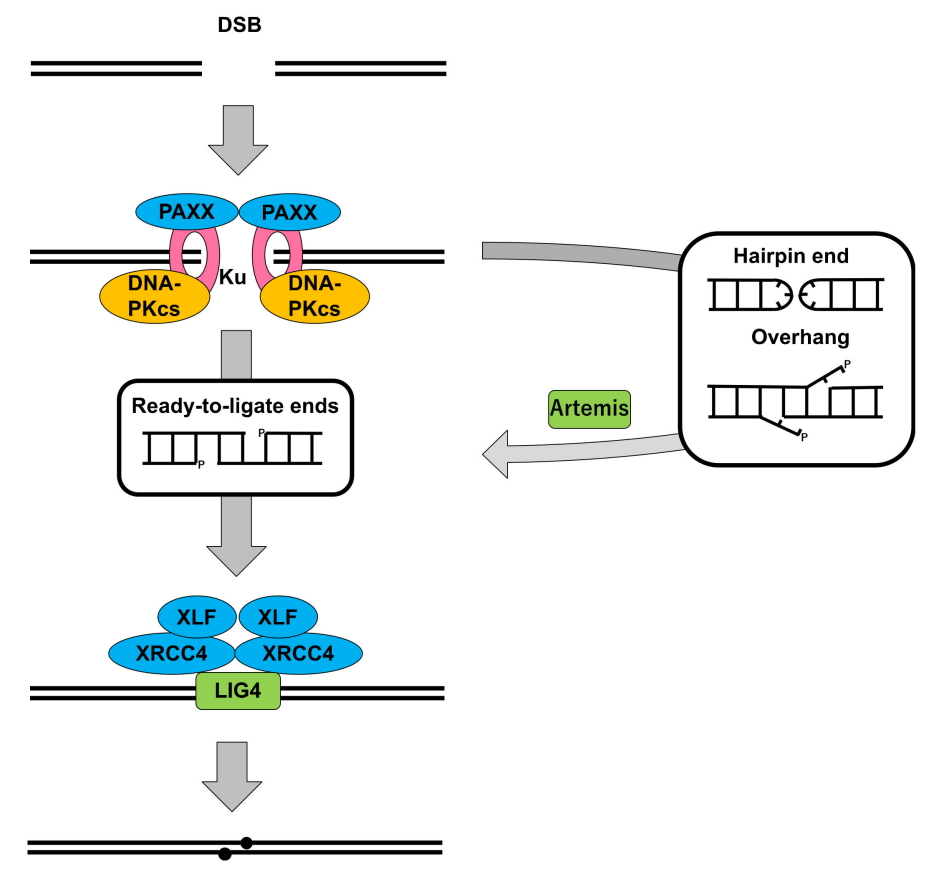

Figure 2. Simplified diagram of DSB repair through NHEJ.

Table 1. DNA-PKcs-deficient cell lines.

\begin{tabular}{|c|c|c|c|c|c|c|}
\hline Cell & Species & Type & Mutation $^{1}$ & DNA-PKcs Status & Characteristics & Ref. \\
\hline scid & Mouse & Fibroblast & $\begin{array}{c}\text { HMZ } \\
\text { c.T12138A, p.Y4046X. } \\
\text { (4128 aa) }\end{array}$ & $\begin{array}{l}\text { Protein very low }(\sim 1 \%) ; \\
\text { DNA binding undetectable; } \\
\text { Kinase activity } \\
\text { undetectable. }\end{array}$ & $\begin{array}{l}\text { Increased IR-sensitivity; } \\
\text { Reduced DSB repair } \\
\text { ability; Defective V(D)J } \\
\text { recombination. }\end{array}$ & $\begin{array}{c}{[10-12,66-} \\
68]\end{array}$ \\
\hline V3 & Hamster & Ovary & $\begin{array}{c}\text { CHTZ; } \\
\text { c.C12070A, p.Q4024X; } \\
\text { Not known in the } \\
\text { other.(4124 aa) }\end{array}$ & $\begin{array}{c}\text { Protein undetectable; } \\
\text { DNA binding barely } \\
\text { detectable; } \\
\text { Kinase activity } \\
\text { undetectable. }\end{array}$ & $\begin{array}{l}\text { Increased IR-sensitivity; } \\
\text { Defective V(D)J } \\
\text { recombination. }\end{array}$ & {$[10,69]$} \\
\hline M059J & Human & Glioma & $\begin{array}{l}\text { LOH; } \\
\text { c.A4051del, } \\
\text { p.T1351Pfs*8. } \\
(4128 \text { aa) }\end{array}$ & $\begin{array}{c}\text { Protein undetectable; } \\
\text { DNA binding barely } \\
\text { detectable; } \\
\text { Kinase activity } \\
\text { undetectable. }\end{array}$ & Increased IR-sensitivity. & {$[17,70]$} \\
\hline Irs-20 & Hamster & Ovary & $\begin{array}{c}\text { CHTZ } \\
\text { c.G12358A, p.E4120K; } \\
\text { 2nd allele not } \\
\text { expressed.(4124 aa) }\end{array}$ & $\begin{array}{c}\text { Protein reduced }\left(\sim 10 \%{ }^{2}\right) \\
\text { DNA binding reduced } \\
\left(\sim 25 \%{ }^{2}\right) \\
\text { Kinase activity } \\
\text { undetectable. }\end{array}$ & $\begin{array}{l}\text { Increased IR-sensitivity; } \\
\text { Defective V(D)J } \\
\text { recombination. }\end{array}$ & {$[69,71]$} \\
\hline SX-9 & Mouse & $\begin{array}{l}\text { Mammary } \\
\text { carcinoma }\end{array}$ & $\begin{array}{c}\text { CHTZ } \\
\text { c.T9572C, p.L3191P; } \\
\text { Not known in the } \\
\text { other. } \\
(4120 \text { aa })\end{array}$ & $\begin{array}{c}\text { Protein reduced }\left(\sim 5 \%{ }^{2}\right) \\
\text { DNA binding reduced } \\
\left(\sim 5 \%{ }^{2}\right) ; \\
\text { Kinase activity } \\
\text { undetectable. }\end{array}$ & $\begin{array}{l}\text { Increased IR-sensitivity; } \\
\text { Defective V(D)J } \\
\text { recombination. }\end{array}$ & {$[71,72]$} \\
\hline XR-C1 & Hamster & Ovary & Unknown. & $\begin{array}{l}\text { Protein undetectable; } \\
\text { Kinase activity } \\
\text { undetectable. }\end{array}$ & $\begin{array}{l}\text { Increased IR- and drug } \\
\text { (bleomycin and ethyl } \\
\text { methane sulfonate) } \\
\text { sensitivity; Defective } \\
\text { V(D)J recombination. }\end{array}$ & [73] \\
\hline
\end{tabular}


Table 1. Cont.

\begin{tabular}{|c|c|c|c|c|c|c|}
\hline Cell & Species & Type & Mutation $^{1}$ & DNA-PKcs Status & Characteristics & Ref. \\
\hline XR-C2 & Hamster & Ovary & $\begin{array}{c}\text { c.G12353A, p.G4118E. } \\
\text { (4124 aa) }\end{array}$ & $\begin{array}{c}\text { Protein expression normal; } \\
\text { Kinase activity } \\
\text { undetectable. }\end{array}$ & $\begin{array}{l}\text { Increased IR- and drug } \\
\text { (bleomycin, ethyl } \\
\text { methane sulfonate and } \\
\text { mitomycin C)-sensitivity; } \\
\text { Reduced DSB repair } \\
\text { ability; Defective V(D)J } \\
\text { recombination. }\end{array}$ & {$[74,75]$} \\
\hline \multicolumn{7}{|c|}{ (Generated by gene targeting or genome editing) } \\
\hline DT40 & Chicken & $\begin{array}{c}\text { B } \\
\text { lymphocyte }\end{array}$ & $\begin{array}{l}\text { p. } 2888-3012 . \\
\quad(4133 \text { aa })\end{array}$ & Protein undetectable. & $\begin{array}{l}\text { Normal proliferation; } \\
\text { Increased IR-sensitivity. }\end{array}$ & [76] \\
\hline HCT116 & Human & $\begin{array}{l}\text { Colon } \\
\text { cancer }\end{array}$ & $\begin{array}{l}\text { p. } 3831-4127 . \\
\quad(4128 \text { aa })\end{array}$ & $\begin{array}{l}\text { Protein undetectable; } \\
\text { Kinase activity } \\
\text { undetectable. }\end{array}$ & $\begin{array}{l}\text { Reduced proliferation; } \\
\text { Increased IR-, drug } \\
\text { (etoposide)-sensitivity; } \\
\text { Telomere shortening; } \\
\text { Increased chromosomal } \\
\text { aberrations. }\end{array}$ & [77] \\
\hline TK6 & Human & $\begin{array}{c}\text { B } \\
\text { lymphocyte }\end{array}$ & $\begin{array}{l}\text { Part of exon } \\
32 \text { replaced with drug } \\
\text { resistance gene. }\end{array}$ & Protein undetectable. & Increased IR-sensitivity. & [78] \\
\hline HAP1 & Human & $\begin{array}{l}\text { Fibroblast- } \\
\text { like, near } \\
\text { haploid }\end{array}$ & $\begin{array}{l}11 \text { bp deletion in exon } \\
25 .\end{array}$ & Protein undetectable. & $\begin{array}{c}\text { Increased drug } \\
\text { (Etoposide)-sensitivity. }\end{array}$ & [79] \\
\hline mESC & Mouse & $\begin{array}{l}\text { Embryonic } \\
\text { stem }\end{array}$ & $\begin{array}{l}\text { c.24del88; p.R9Wfs7*. } \\
\text { (4128 aа) }\end{array}$ & mRNA very low $(<1 \%)$. & $\begin{array}{l}\text { Upregulation of } \\
\text { pluripotency genes. }\end{array}$ & [80] \\
\hline HeLa & Human & $\begin{array}{l}\text { Cervical } \\
\text { carcinoma }\end{array}$ & Targeting exon 36. & Protein undetectable. & Increased IR-sensitivity. & [81] \\
\hline
\end{tabular}

\footnotetext{
${ }^{1}$ HMZ: homozygote, CHTZ: compound heterozygote and LOH: loss of heterozygosity. Numbers in parentheses indicate the number of amino acids of the full-length DNA-PKcs in the respective species. ${ }^{2}$ Estimated from the intensity of the Western blotting bands in the references.
}

Table 2 summarizes the V(D)J recombination ability of DNA-PKcs-deficient cells, measured using extrachromosomal substrates with an exogenous expression of Rag1 and Rag2 (See Appendix A). Coding joint formation is reported to be greatly affected in DNAPKcs-deficient cells, except for XR-C2. However, there is some controversy in the signal joint formation. Some study reported that the frequency of the signal joint was only slightly decreased or not affected at all, whereas others reported significant reductions. Regarding the fidelity, there have been studies reporting only a modest reduction and those reporting profound or complete impairment. The exact reason for this controversy is unknown, but it may have arisen from the differences in DNA-PKcs mutations and/or in cellular backgrounds. In any case, the cording joint formation is more impaired than the signal joint formation in DNA-PKcs-deficient cells. In Ku80- or XRCC4-deficient cells, both the signal joint formation and the coding joint formation are significantly impaired (Table 2). Considering this, the requirement for DNA-PKcs in signal joint formation seems to be less than that for Ku80 or XRCC4. Coding joint formation is thought to be more difficult than signal joint formation, as the former requires opening the hairpin and processing the overhang. Hence, DNA-PKcs might be dispensable for the ligation of "clean" ends, such as blunt ends, but be required for the ligation of "difficult" or "dirty" ends, such as hairpin ends, which need end processing. 
Table 2. V(D)J recombination defects in DNA-PKcs-deficient cells.

\begin{tabular}{|c|c|c|c|c|c|}
\hline \multirow[t]{2}{*}{ Cell } & \multicolumn{2}{|c|}{ Signal Joint } & \multicolumn{2}{|c|}{ Coding Joint } & \multirow[t]{2}{*}{ Ref. } \\
\hline & Frequency & Structure & Frequency & Structure & \\
\hline $\begin{array}{l}\text { Mouse scid } \\
\text { (SCGR11) }\end{array}$ & Normal. & $\begin{array}{c}\text { Fidelity slightly } \\
\text { decreased }(\sim 80 \%) \text {. }\end{array}$ & $\begin{array}{l}\text { Significant decrease } \\
(\sim 3 \%) .\end{array}$ & Larger deletions. & [82] \\
\hline V3 & $\begin{array}{l}\text { Mild decrease } \\
\quad(\sim 20 \%) .\end{array}$ & $\begin{array}{l}\text { Fidelity modestly } \\
\text { decreased }(\sim 50 \%)\end{array}$ & $\begin{array}{l}\text { Significant decrease } \\
(\sim 1 \%) .\end{array}$ & $\begin{array}{l}\text { Abnormally } \\
\text { large P elements. }\end{array}$ & [10] \\
\hline $\begin{array}{l}\text { Mouse scid } \\
(\mathrm{SCID} / \mathrm{St})\end{array}$ & $\begin{array}{c}\text { Substantial } \\
\text { decrease }(\sim 10 \%) .\end{array}$ & Not described. & $\begin{array}{l}\text { Significant decrease } \\
(\sim 0.1 \%) .\end{array}$ & Not described. & [11] \\
\hline IRS-20 & $\begin{array}{c}\text { Substantial } \\
\text { decrease }(\sim 10 \%) .\end{array}$ & $\begin{array}{c}\text { Fidelity slightly } \\
\text { decreased ( } \sim 5 \%) .\end{array}$ & $\begin{array}{l}\text { Significant decrease } \\
(\sim 3 \%) .\end{array}$ & $\begin{array}{l}\text { Smaller deletions } \\
\text { than scid and V3. }\end{array}$ & [69] \\
\hline SX-9 & $\begin{array}{c}\text { Substantial } \\
\text { decrease }(\sim 10 \%) .\end{array}$ & $\begin{array}{l}\text { Fidelity profoundly } \\
\text { decreased }(\sim 10 \%) \text {. }\end{array}$ & $\begin{array}{l}\text { Significant decrease } \\
(\sim 3 \%) .\end{array}$ & $\begin{array}{c}\text { Slightly longer } \\
\text { deletions. }\end{array}$ & [72] \\
\hline XR-C1 & $\begin{array}{l}\text { Significant decrease } \\
(\sim 2 \%) .\end{array}$ & $\begin{array}{c}\text { Correct joins absent } \\
(0 \%) .\end{array}$ & $\begin{array}{l}\text { Significant decrease } \\
\qquad(\sim 2 \%) .\end{array}$ & Not described. & [73] \\
\hline XR-C2 & $\begin{array}{l}\text { Mild decrease } \\
\text { ( 30\%). }\end{array}$ & Not described. & $\begin{array}{l}\text { Mild decrease } \\
\text { ( } 50 \%)\end{array}$ & Not described. & [74] \\
\hline $\begin{array}{c}\text { xrs6 } \\
(\mathrm{Ku} 80)\end{array}$ & $\begin{array}{l}\text { Significant decrease } \\
(\sim 5 \%) .\end{array}$ & $\begin{array}{l}\text { Fidelity profoundly } \\
\text { decreased }(\sim 15 \%) \text {. }\end{array}$ & $\begin{array}{l}\text { Significant decrease } \\
(\sim 1 \%) .\end{array}$ & None recovered. & [82] \\
\hline $\begin{array}{l}\text { XR-V15B } \\
(-K u 80)\end{array}$ & $\begin{array}{l}\text { Undetectable } \\
\qquad(<1 \%) .\end{array}$ & Not described. & Undetectable $(<1 \%)$. & Not described. & [19] \\
\hline $\begin{array}{c}\text { XR-1 } \\
(-X R C C 4)\end{array}$ & $\begin{array}{l}\text { Significant decrease } \\
(\sim 2 \%) .\end{array}$ & $\begin{array}{l}\text { Fidelity profoundly } \\
\text { decreased }(\sim 20 \%) \text {. }\end{array}$ & $\begin{array}{l}\text { Significant decrease } \\
(\sim 0.2 \%) .\end{array}$ & Larger deletions. & {$[45,82]$} \\
\hline
\end{tabular}

\subsection{Animals Deficient for DNA-PKcs: Role in Development}

Table 3 summarizes the DNA-PKcs-deficient animals and their characteristics. The animals show the SCID phenotype, and the cells show increased sensitivity to IR and defective $V(D) J$ recombinations.

Mice with scid mutations show the absence of mature $\mathrm{T}$ and B lymphocytes [13]. The scid mice are highly susceptible to infection by bacteria, viruses and fungi because of an inability to generate an antigen-specific immune response. In addition, scid mice lack transplant rejection and are used for xenografts. However, scid mice are termed "leaky", as they can produce some immunoglobulins and T lymphocytes at increased ages [83]. Murine scid mutations lead to a lack of $\sim 2 \%$ of the C-terminal region, although the protein expression is greatly diminished, and the protein kinase activity is undetectable. Where the coding joint formation is almost completely abrogated, the signal joint formation remains, at least partially. This has raised the possibility that DNA-PKcs in scid is not functionally null. As opposed to this, however, DNA-PKcs knockout (DNA-PKcs ${ }^{-/}$) mice, which were generated by three groups independently, were capable of signal joint formation [84-86]. In addition, mice with slip mutations, which are generated incidentally by the insertion of a transgene to the DNA-PKcs gene and thought to be functionally null, also show a $\sim 10 \%$ ability of signal joint formation without a decrease in fidelity $[87,88]$. These lines of evidence indicate that DNA-PKcs are not absolutely required for signal joint formation. 
Table 3. DNA-PKcs-deficient animals.

\begin{tabular}{|c|c|c|c|c|c|}
\hline Animal & Mutation & DNA-PKcs Status & Animal Phenotype & Cellular Phenotype ${ }^{1}$ & Ref. \\
\hline $\begin{array}{c}\text { Mouse, gene } \\
\text { knockout }\end{array}$ & $\begin{array}{l}\text { Insertion of drug } \\
\text { resistance gene in } \\
\text { exon } 6 .\end{array}$ & $\begin{array}{l}\text { Protein very low } \\
(\sim 1 \%) ; \\
\text { DNA binding } \\
\text { undetectable; } \\
\text { Kinase activity } \\
\text { undetectable. } \\
\text { mRNA undetectable; } \\
\text { Protein undetectable; } \\
\text { Kinase activity } \\
\text { undetectable. }\end{array}$ & $\begin{array}{l}\text { SCID; Increased } \\
\text { thymic lymphomas. }\end{array}$ & $\begin{array}{l}\text { Increased IR-sensitivity; } \\
\text { Reduced DSB repair } \\
\text { ability; Defective V(D)J } \\
\text { recombination (CJ but } \\
\text { not SJ). }\end{array}$ & $\begin{array}{c}{[10-} \\
12,66-68]\end{array}$ \\
\hline $\begin{array}{l}\text { Mouse, gene } \\
\text { knockout }\end{array}$ & $\begin{array}{l}\text { p. } 3860-3950 . \\
(4128 \text { aa })\end{array}$ & $\begin{array}{l}\text { Protein undetectable; } \\
\text { Kinase activity } \\
\text { undetectable. }\end{array}$ & SCID. & $\begin{array}{l}\text { Defective } \mathrm{V}(\mathrm{D}) \mathrm{J} \\
\text { recombination (CJ but } \\
\text { not SJ); Increased } \\
\text { IR-sensitivity } \\
\text { (fibroblast); Normal } \\
\text { IR-sensitivity (ES). }\end{array}$ & [85] \\
\hline $\begin{array}{l}\text { Mouse, gene } \\
\text { knockout }\end{array}$ & $\begin{array}{l}3^{\prime} \text {-half of exon } 3 \\
\text { replaced with drug } \\
\text { resistance gene. }\end{array}$ & Protein undetectable. & SCID. & Increased IR-sensitivity. & [86] \\
\hline Mouse slip & $\begin{array}{l}\text { A transgene inserted } \\
\text { by }>20 \text { copies to } \\
\text { upstream of three } \\
\text { exons corresponding } \\
\text { to } 777-1010 \\
\text { nucleotides of } \\
\text { mRNA. }\end{array}$ & $\begin{array}{l}\text { mRNA undetectable; } \\
\text { Kinase activity } \\
\text { undetectable. }\end{array}$ & $\begin{array}{l}\text { SCID; Increased } \\
\text { thymic lymphomas. }\end{array}$ & Not described. & {$[87,88]$} \\
\hline Mouse, KD & $\begin{array}{l}\text { c.A11765C, } \\
\text { p.D3922A. } \\
(4128 \text { aa })\end{array}$ & $\begin{array}{l}\text { Protein expression } \\
\text { normal; } \\
\text { Kinase activity } \\
\text { undetectable. }\end{array}$ & $\begin{array}{l}\text { Embryonic lethal } \\
\text { (E14.5); Defective } \\
\text { neuronal } \\
\text { development. }\end{array}$ & $\begin{array}{l}\text { Increased IR-sensitivity; } \\
\text { Increased genomic } \\
\text { instability; Defective } \\
\mathrm{V}(\mathrm{D}) \mathrm{J} \text { recombination (CJ } \\
\text { and SJ). }\end{array}$ & [89] \\
\hline $\begin{array}{l}\text { Mouse, } \\
\text { 3A }\end{array}$ & $\begin{array}{c}\text { c.A7813/7900 } \\
/ 7927 \mathrm{G} \\
\text { p.T2605/2634/2643A. } \\
(4128 \text { aa })\end{array}$ & $\begin{array}{l}\text { Protein expression } \\
\text { normal; } \\
\text { Kinase activity } \\
\text { normal. }\end{array}$ & $\begin{array}{l}\text { Born at normal ratio } \\
\text { and size, but becomes } \\
\text { smaller } 2-3 \text { weeks of } \\
\text { age; Death shortly } \\
\text { after birth }(75 \% \text { within } \\
4 \mathrm{w}) \text {; Congenital bone } \\
\text { marrow failure; Loss } \\
\text { of hematopoietic stem } \\
\text { cells. }\end{array}$ & $\begin{array}{l}\text { Increased sensitivity to } \\
\text { IR, UV, CPT and MMC. }\end{array}$ & [90] \\
\hline $\begin{array}{l}\text { Mouse, } \\
\text { Balb/c, } \\
\text { C.B.17, } 129\end{array}$ & $\begin{array}{c}\text { c.C6418T, } \\
\text { p.R2140C/c.A11530G, } \\
\text { p.M3844V. }\end{array}$ & $\begin{array}{l}\text { Protein expression } \\
\text { decreased }(5-10 \%) ; \\
\text { Kinase activity } \\
\text { reduced }(5-10 \%) \text {. }\end{array}$ & $\begin{array}{l}\text { Immunologically } \\
\text { normal; Normal } \\
\text { development; } \\
\text { Increased thymocyte } \\
\text { apoptosis; Susceptible } \\
\text { to cancer, including } \\
\text { breast cancer and } \\
\text { thymic lymphoma. }\end{array}$ & $\begin{array}{l}\text { Delay in DSB repair; } \\
\text { Increased chromosome } \\
\text { instability. }\end{array}$ & [91-93] \\
\hline $\begin{array}{l}\text { Horse SCID } \\
\text { (Arabian } \\
\text { foal) }\end{array}$ & $\begin{array}{l}\text { c.9478del5, } \\
\text { p.S3160Nfs } 4^{*} \text {. } \\
\quad(4134 \text { aa })\end{array}$ & $\begin{array}{l}\text { Protein undetectable; } \\
\text { Kinase activity } \\
\text { undetectable. }\end{array}$ & SCID. & $\begin{array}{l}\text { Increased IR-sensitivity; } \\
\text { Defective V(D)J } \\
\text { recombination (CJ and } \\
\text { SJ). }\end{array}$ & [94-96] \\
\hline $\begin{array}{l}\text { Dog SCID } \\
\text { (Jack Russel } \\
\text { Terriers) }\end{array}$ & $\begin{array}{l}\text { c.G10879A, } \\
\text { p.E3627X. } \\
(4144 \text { aa })\end{array}$ & $\begin{array}{l}\text { Protein undetectable; } \\
\text { DNA binding barely } \\
\text { detectable; } \\
\text { Kinase activity } \\
\text { undetectable. }\end{array}$ & SCID. & $\begin{array}{l}\text { Increased IR-sensitivity; } \\
\text { Defective V(D)J } \\
\text { recombination (CJ and } \\
\text { SJ). }\end{array}$ & {$[97,98]$} \\
\hline
\end{tabular}


Table 3. Cont.

\begin{tabular}{|c|c|c|c|c|c|}
\hline Animal & Mutation & DNA-PKcs Status & Animal Phenotype & Cellular Phenotype ${ }^{1}$ & Ref. \\
\hline $\begin{array}{l}\text { Rat, gene } \\
\text { knockout }\end{array}$ & $\begin{array}{l}\text { Deletion in exon } 1, \\
\text { causing frame-shift. } \\
\text { (4126 aa) }\end{array}$ & $\begin{array}{l}\text { mRNA undetectable; } \\
\text { Protein undetectable. }\end{array}$ & $\begin{array}{l}\text { SCID; } \\
\text { Defective lymphocyte } \\
\text { development; } \\
\text { Growth retardation; } \\
\text { Reduced litter size } \\
(\sim 1 / 2) .\end{array}$ & $\begin{array}{l}\text { Reduced proliferation; } \\
\text { Premature senescence; } \\
\text { IR-sensitivity; Defective } \\
\text { NHEJ. }\end{array}$ & [99] \\
\hline $\begin{array}{l}\text { Zebrafish, } \\
\text { gene } \\
\text { knockout }\end{array}$ & $\begin{array}{l}\text { Frame-shift in exon } 3 . \\
\qquad(4119 \text { aa })\end{array}$ & Protein undetectable. & $\begin{array}{l}\text { SCID; } \\
\text { Growth delay up to } \\
3 \text { months. }\end{array}$ & Not described. & [100] \\
\hline $\begin{array}{l}\text { Zebrafish, } \\
\text { gene } \\
\text { knockout }\end{array}$ & $\begin{array}{l}\text { c.10835del8, } \\
\text { p.D3612Vfs17. } \\
\quad(4119 \text { aa })\end{array}$ & Not described. & $\begin{array}{l}\text { SCID; } \\
\text { IR-sensitivity. }\end{array}$ & Not described. & [101] \\
\hline
\end{tabular}

${ }^{1} \mathrm{CJ}$ : coding joint and SJ: signal joint.

Knockin mice lacking kinase activity (D3922A substitution in the kinase domain, hereafter referred to as KD for kinase dead) and that lack three autophosphorylation sites (T2605/2634/2643A, hereafter referred to as 3A) were generated [89,90]. In DNA$\mathrm{PKcs}{ }^{\mathrm{KD} / \mathrm{KD}}$ mice, the abundance of DNA-PKcs appeared normal, but its kinase activity was undetectable [89]. DNA-PKcs ${ }^{\mathrm{KD} / \mathrm{KD}}$ mice showed late embryonic lethality, dying before embryonic day 14.5 (E14.5) [89]. In the brains of DNA-PKcs ${ }^{\mathrm{KD} / \mathrm{KD}}$ mice, extensive apoptosis was observed at a level similar to LIG4 ${ }^{-/-}$or $\mathrm{XRCC}^{-/-}$mice (see below) [89]. In DNA$\mathrm{PKcs}^{3 \mathrm{~A} / 3 \mathrm{~A}}$ mice, the expression of DNA-PKcs and its kinase activity were normal [90]. Although DNA-PKcs ${ }^{3 \mathrm{~A} / 3 \mathrm{~A}}$ mice were born normally in terms of ratio and size, they become smaller within 2 to 3 weeks of age and died shortly after birth [90]. Congenital bone marrow failure and loss of hematopoietic stem cells were observed in DNA-PKcs $3 \mathrm{~A} / 3 \mathrm{~A}$ mice [90]. The lifespans of DNA-PKcs ${ }^{3 \mathrm{~A} / 3 \mathrm{~A}}$ mice were extended in $\mathrm{p}^{53^{+/-}}$and $\mathrm{p}^{2} 3^{-/-}$ backgrounds with a concomitant alleviation in lymphocyte development defects [90]. This observation suggests that a shortened lifespan and lymphocyte development defects are at least partially due to p53-mediated DNA damage responses, including apoptosis. Cells from DNA-PKcs ${ }^{3 \mathrm{~A} / 3 \mathrm{~A}}$ mice show an elevated sensitivity to DNA crosslinking agents, as well as IR [90]. These characteristics of DNA-PKcs $3 \mathrm{~A} / 3 \mathrm{~A}$ mice were similar to those of Fanconi's anemia. More severe phenotypes of DNA-PKcs ${ }^{\mathrm{KD} / \mathrm{KD}}$ mice and DNA-PKcs ${ }^{3 \mathrm{~A} / 3 \mathrm{~A}}$ mice than that of DNA-PKcs ${ }^{-/-}$mice might be related to the mechanisms of the regulation of DNA-PKcs through phosphorylation by itself and ATM, as we will discuss below.

It might be noted that mice of several strains, including C.B.17, from which scid mice were derived, have hypomorphic DNA-PKcs, although immunologically normal [91,92]. In the Balb/c strain, the expression of DNA-PKcs and DNA-PK kinase activity was 5-10\% of the corresponding tissues and cells from the C57BL/6 strain [91-93]. There were two nucleotide substitutions in the DNA-PKcs gene and resultant amino acid substitutions in the protein in Balb/c compared to C57BL/6: c.C6418T, p.R2140C and c.A11530G and p.M3844V. The Balb/c mice were susceptible to breast cancer and thymic lymphoma and showed increased apoptosis in the thymuses after irradiation [92,93]. The fibroblasts from Balb/c mice showed a reduced DSB repair ability, which is an intermediate of C57BL6 and scid mice. In crossing experiments, the Balb/c allele was associated with an increased risk of thymic lymphoma and chromosome aberrations [92,93].

SCID in horse (Arabian foal) was found earlier than that in mice [94]. Soon after the finding in mice, SCID horses were shown to be deficient in DNA-PKcs $[95,96]$. Unlike the case of scid mice, SCID horses are not reported to be leaky and incapable of signal joint formation, as well as coding joint formation $[95,96]$. SCID animals was also found in dogs (Jack Russel Terriers) and shown to harbor mutations in DNA-PKcs [97,98]. SCID dogs showed intermediate activity in both the signal joint formation and the coding joint formation [98]. Thus, the requirement for DNA-PKcs in V(D)J recombination may differ among species. Meek et al. noted that it may be related to an abundance of DNA-PKcs 
expression and/or DNA-PK kinase activity; the kinase activity, as well as the requirement for DNA-PKcs in V(D)J recombination is the highest in horses and the lowest in mice.

DNA-PKcs ${ }^{-/-}$rats, generated through Zinc-finger nuclease (ZFN)-mediated genome editing, showed SCID without leakiness. In addition, DNA-PKcs ${ }^{-/}$rats showed growth retardation, i.e., smaller body sizes than age-matched DNA-PKcs ${ }^{+/+}$or DNA-PK ${ }^{+-}$ rats [99], which was not noticed in mice, horses and dogs. In agreement with this, the fibroblasts from DNA-PKcs ${ }^{-1-}$ rats showed reduced proliferation and premature senescence [99]. A reduction in litter size was also noted in DNA-PKcs ${ }^{-/-}$rats [99].

Besides mammals, DNA-PKcs ${ }^{-/-}$animals were also generated in zebrafish through transcription activator-like effector nuclease (TALEN)-mediated genome editing [100,101]. DNA-PKCs ${ }^{-/-}$zebrafish also showed the SCID phenotype and competency for xenograft experiments $[100,101]$. Growth retardation was noted at lower ages, i.e., up to 20 weeks, although it was not obvious thereafter [100].

Table 4 shows the comparison of the phenotypes of DNA-PKcs ${ }^{-/}$mice and those of other genes, showing similarities and dissimilarities. $\mathrm{Ku} 80^{-/-}$mice mostly show a complete absence of mature $\mathrm{B}$ and $\mathrm{T}$ lymphocytes and defects in signal joint formation and coding joint formation $[102,103]$. $\mathrm{Ku}^{-/-}$mice showed SCID with some leakiness; although mature B lymphocytes and serum immunoglobulins were absent, mature $\mathrm{T}$ lymphocytes were present, albeit reduced [104,105]. Mouse embryonic fibroblasts (MEF)

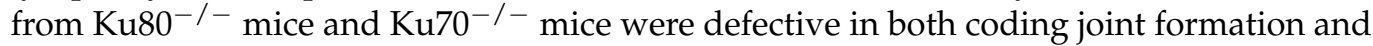
signal joint formation in $\mathrm{V}(\mathrm{D}) \mathrm{J}$ recombination. The reason for the different impact of the loss of $\mathrm{Ku} 80$ and $\mathrm{Ku} 70$ on the T lymphocytes is not known. It may be noted that $\mathrm{Ku} 70^{-/-}$mice, but not $\mathrm{Ku}^{-1-}$ mice, showed an increased frequency of thymic lymphoma [104,106]. Both $\mathrm{Ku}^{-1-}$ mice and $\mathrm{Ku} 70^{-/-}$mice showed a reduction in body sizes, i.e., $40-60 \%$ of the control and litter sizes [102-104], which were not in evident in scid mice and DNA$\mathrm{PKCs}^{-/-}$mice. In conjunction with this, MEF from $\mathrm{Ku} 80^{-/-}$mice and $\mathrm{Ku}^{-/-}$mice showed reduced proliferation and premature senescence [103-105]. Increased cell death in neuronal development was also observed in $\mathrm{Ku}^{-1-}$ mice and $\mathrm{Ku} 80^{-/-}$mice [107], although it was less severe than that observed in $\mathrm{LIG}^{-/-}$mice and $\mathrm{XRCC}^{-/-}$mice (see next).

$\mathrm{LIG}^{-/-}$mice and XRCC4 ${ }^{-/-}$mice exhibited late embryonic lethality [108-110]. MEF from $\mathrm{LIG} 4^{-/-}$mice and $\mathrm{XRCC} 4^{-/-}$mice showed reduced proliferation and premature senescence, as well as an increased sensitivity to IR [108-110]. Mature B and T lymphocytes were absent in these mice, and the fibroblasts were defective in both coding joint formation and signal joint formation in V(D)J recombination. In addition, the defective neuronal development associated with greatly increased cell death was manifested in LIG4 ${ }^{-/-}$mice and XRCC4 ${ }^{-/-}$mice $[109,110]$.

Artemis $^{-/-}$mice grew normally but were deficient in lymphocyte development [111]. Artemis $^{-/-}$MEF showed increased IR sensitivity [111]. While coding joint formation in Artemis $^{-/-}$MEF was greatly impaired, signal joint formation was indistinguishable from the wild-type in rate and fidelity [111]. Since DNA-PKCs ${ }^{-/}$MEF showed mildly reduced fidelity, DNA-PKcs might have an Artemis-independent function in signal joint formation.

$\mathrm{XLF}^{-/-}$mice did not exhibit overt defects in growth and development [112]. There was a slight decrease in the number of lymphocytes, but the distribution of mature lymphocytes was normal, although a mild defect in the class switch recombination (CSR) was evident [112]. However, ES cells or MEFs showed increased IR sensitivity and V(D)J recombination defects in both signal joint formation and coding joint formation [112]. These results suggested the presence of a lymphocyte-specific mechanism to compensate for a XLF deficiency. XLF is shown to have functional redundancy with ATM [113], DNAPKcs [114] and PAXX (see next). Of note, DNA-PKcs ${ }^{-/-} ; \mathrm{XLF}^{-/-}$mice showed a reduction in birth ratio and body size at birth [114]. Additionally, signal joint formation in V(D)J recombination was compromised in DNA-PKcs ${ }^{-/-} ; \mathrm{XLF}^{-/-}$mice, although it was mostly normal in Artemis ${ }^{-/-}, \mathrm{XLF}^{-/-}$mice $[113,114]$. This observation further supports the Artemis-independent function of DNA-PKcs in signal joint formation. 
Table 4. Gene knockout mice of DNA-PKcs and other NHEJ genes.

\begin{tabular}{|c|c|c|c|c|c|}
\hline Mice & Viability & Growth & Neurogenesis & Immunity $^{1}$ & Ref. \\
\hline DNA-PKcs ${ }^{-/-}$ & Viable. & Normal body size. & Normal. & $\begin{array}{l}\text { SCID (leaky); SJ: normal } \\
\text { or modestly impaired; CJ: } \\
\text { impaired. }\end{array}$ & {$[84-86,107]$} \\
\hline $\mathrm{Ku} 80^{-/-}$ & Viable. & $\begin{array}{l}\text { Reduced body } \\
\text { size. }\end{array}$ & $\begin{array}{l}\text { Defective (milder than } \\
\text { XRCC4-/- and } \\
\text { LIG4 }^{-/-} \text {); Increased } \\
\text { cell death. }\end{array}$ & SCID; SJ \& CJ: defective. & {$[102,103,107]$} \\
\hline $\mathrm{Ku}^{-1-}$ & Viable. & $\begin{array}{l}\text { Reduced body } \\
\text { size. }\end{array}$ & $\begin{array}{l}\text { Defective (milder than } \\
\text { XRCC4 } 4^{-/} \text {and } \\
\text { LIG4 }^{-/-} \text {); Increased } \\
\text { cell death. }\end{array}$ & $\begin{array}{l}\text { SCID (leaky); SJ \& CJ: } \\
\text { defective. }\end{array}$ & {$[104,105,107]$} \\
\hline $\mathrm{LIG}_{4}^{-/-}$ & $\begin{array}{l}\text { Late embryonic } \\
\text { lethality (>E13.5) }\end{array}$ & $\begin{array}{l}\text { Reduced body size } \\
\text { in uterus. }\end{array}$ & $\begin{array}{l}\text { Severely defective; } \\
\text { Massive cell death. }\end{array}$ & SCID; SJ \& CJ: defective. & {$[108,109]$} \\
\hline $\mathrm{XRCC}_{4}^{-/-}$ & $\begin{array}{l}\text { Late embryonic } \\
\text { lethality (>E13.5) }\end{array}$ & $\begin{array}{l}\text { Reduced body size } \\
\text { in uterus. }\end{array}$ & $\begin{array}{l}\text { Severely defective; } \\
\text { Massive cell death. }\end{array}$ & SCID; SJ \& CJ: defective. & [110] \\
\hline Artemis $^{-/-}$ & Viable. & Normal body size. & Normal. & $\begin{array}{l}\text { SCID (leaky); SJ: normal; } \\
\text { CJ: impaired. }\end{array}$ & [111] \\
\hline $\mathrm{XLF}^{-/-}$ & Viable. & Normal body size. & Normal. & $\begin{array}{l}\text { Mostly normal; Slight } \\
\text { decrease in the number of } \\
\text { lymphocytes; Normal } \\
\text { lymphocyte distribution; } \\
\text { Mild defect in CSR. }\end{array}$ & [112] \\
\hline $\mathrm{PAXX}^{-/-}$ & Viable. & Normal body size. & Normal. & $\begin{array}{l}\text { Mostly normal; Modest } \\
\text { decrease in the number of } \\
\text { lymphocytes. }\end{array}$ & {$[115,116]$} \\
\hline
\end{tabular}

${ }^{1}$ SJ: signal joint formation and CJ: coding joint formation.

$\mathrm{PAXX}^{-/-}$mice also showed normal growth and development, although they showed a slightly reduced survival after $\gamma$-ray irradiation $[115,116]$. PAXX ${ }^{-/-} ; \mathrm{XLF}^{-/-}$mice were embryonic lethal, dying between E14.5 and E18.5. A reduced body size became evident at around E10.5 [115,116], suggesting possible redundant functions between PAXX and XLF.

These lines of evidence indicate that NHEJ is essential in growth and development. We can also see that the requirement for DNA-PKcs is less pronounced than that of Ku70, Ku80, XRCC4 and LIG4.

\subsection{Human Patient and Cells Deficient in DNA-PKcs: Manifested Importance in Human}

To date, six human individuals have been reported to harbor homozygous or compound heterozygous mutations in DNA-PKcs, as shown in Table 5. Five patients (P1 and P3-P5) are of Turkish origin and have a common homozygotic mutation. Of two mutations, i.e., one deletion and one substitution of amino acid in each allele, the latter is considered responsible for the disease [117]. It is noteworthy that the expression of DNA-PKcs, its autophosphorylation on Ser2056 and kinase activity appeared normal in the fibroblast derived from P1 [117]. Moreover, when exogenously expressed in V3 cells, the mutated gene could accumulate on DNA damage induced by laser micro-irradiation and recruit Artemis there as well [117]. These lines of evidence indicate that this mutation is hypomorphic, retaining a substantial part of the DNA-PKcs functions. Nevertheless, this mutation increased the length of the P-nucleotide in the coding joint, as in the case of patients with mutations in Artemis, indicating that this mutant might be defective in the activation of Artemis [117]. Other patients with the same mutations showed granuloma and/or autoimmunity, as well as SCID [118,119]. 
Table 5. Human patients deficient in DNA-PKcs.

\begin{tabular}{|c|c|c|c|c|c|c|}
\hline Patient & Gender & $\begin{array}{l}\text { Ethnic } \\
\text { Origin }\end{array}$ & $\begin{array}{c}\text { Mutation }{ }^{1} \text { and DNA-PK } \\
\text { Status }\end{array}$ & $\begin{array}{c}\text { Clinical } \\
\text { Characteristics }\end{array}$ & $\begin{array}{c}\text { Cellular } \\
\text { Characteristics }\end{array}$ & Ref. \\
\hline $\begin{array}{c}\text { P1 } \\
\text { (ID177) }\end{array}$ & $\mathrm{F}$ & Turkish & $\begin{array}{c}\text { HMZ } \\
\text { c.6338del3, p.G2113del/ } \\
\text { c.T9185G, p.L3062R. } \\
\text { Protein expression normal; } \\
\text { Kinase activity normal. }\end{array}$ & SCID. & $\begin{array}{l}\text { Increased } \\
\text { IR-sensitivity; } \\
\text { Delay in DSB } \\
\text { repair. }\end{array}$ & [117] \\
\hline $\begin{array}{c}\text { P2 } \\
(\mathrm{NM} 720)\end{array}$ & M & British & $\begin{array}{c}\text { CHTZ; } \\
\text { c. exon16; } \\
\text { c.C10721T, p.A3574V. } \\
\text { Protein very low }\left(\sim 5 \%{ }^{2}\right) ; \\
\text { Kinase activity undetectable. }\end{array}$ & $\begin{array}{l}\text { SCID; Growth failure; } \\
\text { Microcephaly; Facial } \\
\text { dysmorphism; } \\
\text { Seizures; Bilateral } \\
\text { sensorineural hearing } \\
\text { loss; Visual } \\
\text { impairment; Died at } \\
31 \text { months. }\end{array}$ & $\begin{array}{l}\text { Increased } \\
\text { IR-sensitivity; } \\
\text { Delay in DSB } \\
\text { repair. }\end{array}$ & [120] \\
\hline P3 & M & Turkish & $\begin{array}{c}\text { HMZ } \\
\text { c.6338del3, p.G2113del/ } \\
\text { c.T9185G, p.L3062R. }\end{array}$ & $\begin{array}{l}\text { SCID; Granuloma; } \\
\text { Autoimmunity. }\end{array}$ & Not described. & [118] \\
\hline P4 & $F$ & Turkish & $\begin{array}{c}\text { HMZ } \\
\text { c.6338del3, p.G2113del/ } \\
\text { c.T9185G, p.L3062R. }\end{array}$ & $\begin{array}{l}\text { SCID; Granuloma; } \\
\text { Autoimmunity. }\end{array}$ & Not described. & [118] \\
\hline P5 & $\mathrm{F}$ & Turkish & $\begin{array}{c}\text { HMZ } \\
\text { c.6338del3, p.G2113del/ } \\
\text { c.T9185G, p.L3062R. }\end{array}$ & $\begin{array}{l}\text { SCID; Granuloma; } \\
\text { Arthritis. }\end{array}$ & Not described. & [119] \\
\hline P6 & $\mathrm{F}$ & Turkish & $\begin{array}{c}\text { HMZ } \\
\text { c.6338del3, p.G2113del/ } \\
\text { c.T9185G, p.L3062R. }\end{array}$ & $\begin{array}{l}\text { SCID; Granuloma; } \\
\text { Diarrhea. }\end{array}$ & Not described. & [119] \\
\hline
\end{tabular}

${ }^{1}$ HMZ: homozygote and CHTZ: compound heterozygote. ${ }^{2}$ Estimated from the intensity of the Western blotting bands in the references.

One patient (P2) of British origin had a distinct compound heterozygotic mutation [120]. This patient was first given clinical attention due to poor intrauterine growth and, after birth, showed various symptoms, including microcephaly, facial dysmorphism, seizures and other neurological abnormalities, in addition to SCID [120]. He died at 31 months of age because of intractable seizures [120]. Unlike the case of P1, the expression of DNA-PKcs in the fibroblast from P2 was very low, and the kinase activity was not detectable [120]. These observations suggested a more severe defect in DNA-PKcs functions in P2 than in P1, causing growth and neuronal defects in addition to immunodeficiency. Nonetheless, the DNA-PKcs in this patient might have been partially functional, because the treatment of fibroblasts from the patient prolonged the decline of the $\gamma-\mathrm{H} 2 \mathrm{AX}$ foci after IR [120]. Additionally, the A3574V mutant could partially restore the coding joint proficiency, with normal sequence, to DNA-PKcs-deficient V3 cells, suggesting that this mutant is capable of activating Artemis [120].

Thus, human individuals with null-functional DNA-PKcs have not been found so far and might not be viable at all. In addition, the attempts to establish $\mathrm{Ku}^{-1} 0^{-}$and $\mathrm{Ku} 80^{-/-}$cells from HCT116 or Nalm- 6 failed, and these genes proved indispensable for the viability of human cells [121-123]. The lethality might be due to telomere deletion in the form of telomeric circles, which should be suppressed by Ku86 [123]. Ku86 was also shown to suppress alternative, DNA polymerase $\theta$-mediated NHEJ (A-NHEJ, A-EJ or TMEJ), which are thought more susceptible to errors than classical NHEJ [124]. The expression of DNA-PKcs and DNA-PK kinase activity in human cells were reported to be higher than in rodent cells by one or two orders of magnitude $[11,17,96]$. Human colon cancer HCT116 cells exhibit a haploinsufficiency of DNA-PKcs in terms of various functions; DNA-PKcs ${ }^{+/-}$showed a slower proliferation and higher sensitivity to IR and 
etoposide, as well as a shorter telomere length than DNA-PKcs ${ }^{+/+}$cells [77] (Table 1). Ku70 and Ku80 also exhibit haploinsufficiency in terms of cell proliferation, IR sensitivity and telomere length [121-125]. On the other hand, cells lacking XRCC4 or LIG4 were established from several cell lines and were shown to be viable $[78,79,126-130]$. This is in contrast to the situation in mice, where the absence of XRCC4 and LIG4 results in more severe consequences than the absence of Ku70 or Ku80. These lines of evidence indicate that the importance of DNA-PKcs and Ku might be manifested in humans as compared to other mammalian species.

\section{Relationship between DNA-PKcs and ATM}

\subsection{Overlap and Nonoverlap in Functions between DNA-PKcs and ATM}

$\mathrm{ATM}^{-/-}$mice showed growth retardation, neurological dysfunction, immunodeficiency, infertility and increased tumor susceptibility, as observed in human AT patients [131,132]. As the mice doubly deficient for ATM and DNA-PKcs, Ku80 or Ku70 showed early embryonic lethality (E11.5-13.5) [133,134]. This is substantially different in timing from the late embryonic lethality (after E13.5) observed in LIG4 ${ }^{-/-}$or XRCC4 ${ }^{-/-}$ mice. Cultured cells deficient in ATM and DNA-PKcs have not been established to date and are thought to be inviable. Therefore, ATM and DNA-PKcs are thought to have partially overlapping roles required to sustain cell survival and animal development.

Eriquez-Rios et al. [135] examined the interrelationship of DNA-PKcs, ATM and ATR in the brains of mice embryos using DNA-PKcs ${ }^{-/-}$mice, neuron-specific ATM/ATR

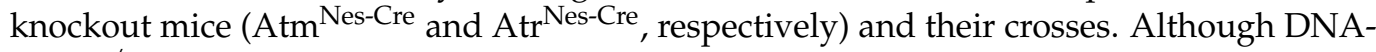
$\mathrm{PKcs}^{-1-}$ mice have shown normal neural development, increased DNA damage and apoptosis were observed after irradiation, especially in postmitotic cells [135]. This observation indicated the role of DNA-PKcs in protecting cells from DNA damage and apoptosis [135]. This function might be manifested in human, and its impairment might lead to neuronal abnormalities, as observed in one of the reported patients (P2) [135]. The radiation-induced apoptosis was less pronounced in DNA-PKCs ${ }^{-/-} ; \mathrm{Atm}^{\mathrm{Nes}-\mathrm{Cre}}$ than DNA-PKcs ${ }^{-/-}$, indicating that ATM regulates apoptosis [135]. Atr ${ }^{\text {Nes-Cre mice showed }}$ increased M-phase cells in proliferating cells, indicating a defective G2/M checkpoint [135]. Thus, in developing neuronal systems, DNA-PKcs, ATM and ATR seem to play major roles in DNA repair, apoptosis and the cell cycle checkpoint, respectively.

A fibroblast cell line from an AT patient was shown to be proficient in the signal joint formation and coding joint formation of extrachromosomal plasmid substrates [136]. However, the coding joint formation of the chromosome-integrated substrate was reduced in pre-B cells from $\mathrm{ATM}^{-/-}$mice, as compared to $\mathrm{ATM}^{+/+}$mice [137]. $\mathrm{ATM}^{-/-}$mice also exhibited impairment in the maturation of $\mathrm{B}$ cells and $\mathrm{T}$ cells due to defective coding joint formation in immunoglobulin and TCR $\alpha[138,139]$. On the other hand, the signal joint formation appeared mostly normal in $\mathrm{ATM}^{-/-}$mice [113]. Gapud et al. [140] and Zha et al. [141] demonstrated that the treatment of DNA-PKcs ${ }^{-/-}$cells and $\mathrm{ATM}^{-/-}$cells with an ATM inhibitor (ATMi) and DNA-PK inhibitor (DNA-PKi), respectively, resulted in impairment of the signal joint formation. Zha et al. also showed similar results by the conditional knockout of the DNA-PKcs gene in the ATM ${ }^{-/-}$background [141]. These results indicated that DNA-PKcs and ATM have redundant roles in signal joint formation. As described above, the kinase activity of DNA-PKcs is required for $\mathrm{V}(\mathrm{D}) \mathrm{J}$ recombination, as well as the repair of radiation-induced DSBs. Since DNA-PKcs and ATM share similar biochemical properties, there can be redundancy between these kinases in the phosphorylation of protein(s), which is discussed next.

\subsection{Overlap and Nonoverlap in Protein Phophorylation by DNA-PKcs and ATM in NHEJ}

Artemis is shown to be capable of opening the hairpin end and processing the overhang in a manner dependent on DNA-PKcs and its kinase activity [51]. Where Artemis was shown to be phosphorylated by DNA-PK at 11 sites in vitro [142,143], the mutants lacking these phosphorylation sites did not show a reduction in the enzymatic activities 
and V(D)J recombination functions [142-144]. It was shown that the autophosphorylation of DNA-PKcs was required for Artemis activation [144]. IR-induced Artemis phosphorylation in cellulo was shown to be mediated by ATM, as well as DNA-PKcs [142-147]. It was shown later that DNA-PK kinase activity was dispensable for coding joint formation when three phosphorylation sites by ATM were present and the ATM activity was not perturbed [148]. This observation suggests that, at least one of the redundant function(s) of DNA-PKcs and ATM in coding joint formation is to phosphorylate DNA-PKcs itself. In addition to coding joint formation, the interaction of Artemis and ATM was implicated in the cell cycle checkpoint [145] and HR [146].

XRCC4 was shown to be phosphorylated by DNA-PK in vitro $[46,149,150]$ and in cellulo in response to IR [151]. Ser260 and Ser320 (Ser318 in an alternatively spliced form) were identified as the major phosphorylation sites in vitro [152,153]. The phosphorylation of these serines in cellulo in response to IR is mostly diminished by treatment with a DNAPK inhibitor or in DNA-PKcs-deficient cells $[154,155]$. On the other hand, the ATM inhibitor alone did not show a discernable reduction in phosphorylation $[154,155]$, indicating that XRCC4 phosphorylation at these sites is mostly mediated through DNA-PK. However, the XRCC4 mutants lacking these phosphorylation sites retained normal functions in in the restoration of radioresistance and $\mathrm{V}(\mathrm{D}) \mathrm{J}$ recombination in XRCC4-deficient cells and, also, in the DNA joining reaction in the cell-free system $[152,153]$, although it was also reported that the mutant lacking Ser260 showed a slight but significant increase in radiosensitivity and decrease in DSB repair ability [155]. There are additional phosphorylation sites in XRCC4 by DNA-PK, and further studies are required to clarify the significance of phosphorylation. Normanno et al. [156] replaced eight potential phosphorylation sites (Ser193, Ser260, Ser304, Ser315, Ser320, Thr323, Ser327 and Ser328) in XRCC4 with alanine or aspartate and showed that none of them could fully restore the radioresistance of the XRCC4-deficient cells. It was also shown that the aspartate-substituted (phospho-mimic) mutant showed a decreased DNA bridging ability and increased dissociation of the XRCC4-XLF complex in DNA [156]. It may be noted that seven of the potential phosphorylation sites, i.e., except for Ser193, are located in the intrinsically disordered C-terminal region of XRCC4 and that four of them are clustered in the XRCC4 extremely C-terminal (XECT) region, which is unique to and highly conserved among vertebrates [157].

XLF was also shown to be phosphorylated by DNA-PK in vitro, and Ser245 and Ser251 were identified as the major phosphorylation sites [158]. In cellulo, Ser245 is phosphorylated by DNA-PK, whereas Ser251 is phosphorylated by ATM [158]. However, the XLF mutant lacking these phosphorylation sites could restore the radioresistance and DSB repair ability to XLF-deficient cells, indicating that the phosphorylation of XLF at these sites is dispensable for DNA repair function [158]. As in the case of XRCC4, Normanno et al. [156] generated mutants, in which six potential phosphorylation sites (Ser132, Ser203, Ser245, Ser251, Ser263 and Ser266) were substituted with alanine and aspartate, and showed that none of them could fully restore the radioresistance of XLFdeficient cells [156]. The aspartate-substituted (phospho-mimic) mutant of XLF showed a reduced DNA bridging ability and increased the dissociation of the XRCC4-XLF complex from DNA [156].

The accumulated evidence indicates the main function of DNA-PK in NHEJ and that of ATM in HR and the cell cycle checkpoints. As seen above, the role of the protein phosphorylation by DNA-PK in NHEJ is still largely unclear, demanding further studies. DNA-PK is also shown to phosphorylate a great number of proteins in vitro and in vivo, which are not currently implicated in NHEJ (as reviewed in reference [20]). The first reported substrate of ATM was p53 $[37,88]$. Thereafter, ATM was shown to phosphorylate a number of proteins in vitro and in vivo, including NBS1 [159-161] and BRCA1 [162,163], which are implicated in HR and the cell cycle checkpoints. ATM and DNA-PKcs have a redundant function in the phosphorylation of H2AX on Ser139 $(\gamma-\mathrm{H} 2 \mathrm{AX})$, where ATM plays a major role [164,165]. $\gamma$-H2AX is thought to serve as the "landmark" of DSB. The mediator of DNA damage checkpoint protein 1 (MDC1) binds first to $\gamma-\mathrm{H} 2 \mathrm{AX}$ and, in turn, 
recruits a series of proteins involved in DSB repair and the cell cycle checkpoint through direct or indirect protein-protein interactions [166]. Matsuoka et al. identified more than 900 phosphorylation sites on more than 700 proteins, which were phosphorylated by ATM or ATR in cellulo, through stable amino acid-labeling in the cell culture (SILAC) combined with mass spectrometry [167]. This evidence suggests extensive networks of DNA damage responses and versatile functions of DNA-PKcs, ATM and ATR therein.

\subsection{Regulation of DNA-PKcs and ATM by Phosphorylation}

In the earliest studies of DNA-PK, it was noticed that DNA-PKcs could phosphorylate itself, i.e., autophosphorylation [2,3]. Since the first identification of autophosphorylation site Thr2609 in 2002 [168], more than 40 serines/threonines have been shown to undergo autophosphorylation in vitro [169-174]. There are two major clusters of phosphorylation sites, i.e., the ABCDE cluster around Thr2609 $[169,170]$ and the PQR cluster around Ser2056 $[175,176]$. Many of them are phosphorylated in response to IR or DNA-damaging agents and essential for DNA repair function [168-174]. Where the phosphorylation sites in the PQR clusters seems to be autophosphorylated [177], those in the ABCDE cluster are likely phosphorylated by ATR or ATR rather than DNA-PKcs [178]. The phosphorylation in the $\mathrm{ABCDE}$ cluster was shown to be essential for the stimulation of Artemis endonuclease activity [148].

It was demonstrated that the autophosphorylation of DNA-PKcs or substitution of serines or threonines in the $\mathrm{ABCDE}$ cluster with aspartate to mimic phosphorylation facilitate NHEJ, possibly through changing the conformation of DNA-PKcs itself and increasing the accessibility of repair enzymes to DNA ends $[177,179]$. Phosphorylation in the ABCDE cluster is also required for the pathway choice between NHEJ and HR. The mutant DNAPKcs lacking ABCDE phosphorylation sites behaved "even worse" than the functionally null DNA-PKcs. When the mutant was introduced into V3, the transfectant showed higher radiosensitivity than the empty vector transfectant [172-174]. As mentioned earlier, the mice lacking three of these phosphorylation sites (DNA-PKcs ${ }^{3 \mathrm{~A} / 3 \mathrm{~A}}$ ) died shortly after birth due to severe bone marrow failure [90]. DNA-PKcs ${ }^{3 \mathrm{~A} / 3 \mathrm{~A}} \mathrm{MEF}$ showed hypersensitivity to DNA crosslinking agents, like Fanconi's Anemia (FA) cells, and defects in the HR and FA pathways [90]. The disruption of ABCDE phosphorylation sites might result in the persistence of DNA-PKcs on DSB, preventing it from the HR or FA pathways.

The autophosphorylation of ATM was first shown using the proteins expressed in baculovirus [180]. In 2003, Bakkenist and Kastan showed that ATM undergoes autophosphorylation at Ser1981, which is required for ATM activation through dissociation of the dimer [181]. Since then, the phosphorylation status of ATM Ser1981 has been used extensively as a marker for ATM activation and the cellular response to DSB. The phosphorylation of ATM Ser1981 was also induced after UV irradiation in a manner dependent on ATR rather than ATM [182]. Kozlov et al. identified several additional autophosphorylation sites, including Ser367, Ser1893 [183], Thr1985 and Ser2996 [184], and demonstrated the phosphorylation in cellulo in response to radiation in a manner dependent on ATM and Nbs1. The serines corresponding to Ser1981, Ser367 and Ser1893 in mice were shown to be dispensable for ATM activation $[185,186]$. On the other hand, the autophosphorylation of Ser1981 was shown to be required for the sustained retention of ATM at DNA-damaged sites [187]. Ser367- or Ser2996-phosphorylated ATM accumulated in heavy ion-induced DNA damage, although they were not required for the accumulation [184]. These serines were required for the S-phase checkpoint function (i.e., to correct the radioresistant DNA synthesis of cells in AT patients) [184].

In 2017, Zhou et al. showed that DNA-PK phosphorylated ATM and MRN in vitro [188]. The phosphorylation of ATM by DNA-PK in vitro inhibited ATM kinase activity [188]. Changing the serines and threonines in two clusters (S85/T86, T372/T373 and T1985/ S1987/S1988) into glutamate, mimicking phosphorylation, abolished the ATM activation by MRN and DNA [188]. These mutants showed a deficiency in ATM functions [188]. On the other hand, some the mutants blocking this phosphorylation showed a resistance 
to the inhibitory effects by DNA-PK. Their study demonstrated that DNA-PK negatively regulates the ATM function through phosphorylation.

Thus, there is accumulating evidence indicating mutual regulation between DNA-PK and ATM through phosphorylation. As there are many potential sites for autophosphorylation and mutual phosphorylation in DNA-PKcs and ATM, further studies are required.

\section{Conclusive Remarks}

DNA-PK, comprised of DNA-PKcs and Ku, acts as the DSB sensor, which is essential for the repair of DSB through NHEJ. As compared to the other factors in NHEJ, DNA-PKcs is especially important for the ligation of "difficult" or "dirty" ends, which need processing before ligation. However, the precise role of the protein phosphorylation in NHEJ remains a great missing link. In addition, the characteristics of animals and human individuals with defective NHEJ show its importance in development, which is manifested in the neuronal and immune systems. DNA-PK has pleiotropic functions beyond DSB repair, which are reviewed elsewhere [20,189]. DNA-PK, as well as other NHEJ factors, are also implicated in carcinogenesis and considered promising targets for cancer therapeutics. There are also many reviews of these aspects, including reference [190].

DNA-PKcs share a similarity in the primary structure and properties with ATM, which is also implicated in cellular responses to DSBs. Compared to DNA-PKcs, ATM shows more pronounced importance in the cell cycle checkpoint. Nevertheless, there are substantial overlaps in the function and protein phosphorylation between DNA-PKcs and ATM. It is also important that DNA-PKcs and ATM undergo extensive and complex regulations through autophosphorylation and mutual phosphorylation.

Since the first identification of DNA-PK activity in animal cell extracts, studies over 35 years have greatly promoted our understanding of the functions and regulatory mechanisms of DNA-PKcs and ATM. However, considering the enormous sizes of these molecules and vast number of substrate proteins and phosphorylation sites therein, our current knowledge might be just the tip of the iceberg, warranting further studies. The outcomes of this research will surely contribute to the etiology and therapeutics of cancer and developmental diseases.

Author Contributions: Conceptualization, Y.M.; investigation, Y.M., A.D.D.C.A., C.M. and M.S.; data curation, Y.M.; writing—original draft preparation, Y.M.; writing-review and editing, A.D.D.C.A., C.M. and M.S.; visualization, Y.M., A.D.D.C.A., C.M. and M.S.; supervision, Y.M.; project administration, Y.M. and funding acquisition, Y.M. All authors have read and agreed to the published version of the manuscript.

Funding: This study was funded by Grant-in-Aid for Scientific Research (24390290, 15 H02817 and 20H04334) and Challenging Research (25550024 and 17K20042) from Japan Society for the Promotion of Science (JSPS) to Y.M.

Institutional Review Board Statement: Not applicable.

Informed Consent Statement: Not applicable.

Data Availability Statement: Not applicable.

Acknowledgments: We thank the ex- and current members of our laboratory, especially Mukesh Kumar Sharma, for their continuous support. We apologize for not citing many important works due to space limitations.

Conflicts of Interest: The authors declare no conflict of interest.

\section{Appendix A. V(D)J Recombination}

Humans, as well as other vertebrates, have an enormous repertoire of immunoglobulins (Igs) and T-cell receptors (TCR), which enables our immune systems to recognize virtually any foreign antigens. One human individual can produce more than $10^{8}$ types of 
Igs. As the human genome has only $6 \times 10^{9}$ base pairs, this diversity is generated by the "shuffling" of genetic materials, which is known as V(D)J recombination $[175,176]$.

An Ig consists of two identical heavy chains and two identical light chains. The variable region of the heavy chain is composed of the variable $(\mathrm{V})$, diversity (D) and joining (J) segments and is connected to the constant (C) region (Figure A1a). There are about 50 heavy-chain $\mathrm{V}$ gene segments, $30 \mathrm{D}$ gene segments and $6 \mathrm{~J}$ gene segments in the human immunoglobulin heavy chain locus, which is located in chromosome 14 [191]. As one each of the $\mathrm{V}, \mathrm{D}$ and $\mathrm{J}$ segments are randomly selected in each $\mathrm{B}$ cell, the possible combinations amount to $50 \times 30 \times 6=9000$. There are two types of light chains, i.e., the $\kappa$ chain and $\lambda$ chain, and each $B$ cell expresses either one of them. The $\mathrm{K}$ chain and $\mathrm{l}$ chain are composed of $\mathrm{V}$ and $\mathrm{J}$ segments and have several hundreds of combinations. As a result, the possible combinations of heavy chains and light chains amount to the order of $10^{6}-10^{7}$. The diversity of each chain is further increased by the insertion and deletion of nucleotides at the junction (see below) and somatic hypermutation. A similar mechanism works in the assembly of TCR, which consists of $\alpha$ and $\beta$ chains or $\gamma$ and $\delta$ chains.

To assure that V(D)J recombination occurs only at specific sites of Ig and TCR genes, the V, D and J segments are flanked by recombination signal sequences (RSSs) (Figure A1b). There are two different types of RSSs, which differ from each other in the length of the spacer between the consensus heptamer (CACAGTG) and nonamer (ACAAAAACC) elements, i.e., 12-RSS and 23-RSS for the spacers of $12 \mathrm{bp}$ and $23 \mathrm{bp}$, respectively. V(D)J recombination occurs between a gene segment flanked by 12-RSS and that is flanked by 23-RSS ("the12/23 rule"). Two lymphoid-specific factors, Recombination activating genes 1 and 2 (RAG1 and RAG2) [192,193], form an enzyme complex that recognizes a proper pair of RSSs and causes DNA double-stranded breaks. This involves an introduction of a nick at the $5^{\prime}$ end of the partner RSS by the RAG proteins and the coupled cleavage of both RSS using 3-OH, which is a result of nicking. These result in the coding ends with a hairpin structure and the signal end, which is blunt [194]. Then, the broken DNA are joined through NHEJ. The signal ends can be joined directly without any insertion or deletion of the nucleotides. On the other hand, the coding ends require opening of the hairpin structure and the processing of overhangs so that they are ready for ligation. Asymmetric opening of the hairpin results in the appearance of palindromic nucleotides (P-nucleotides). In addition, several nucleotides are added randomly to the $3^{\prime}$ end by Terminal deoxyribonucleotidyl transferase (TdT), producing non-templated nucleotides (N-nucleotides) [176].

One conventional assay for V(D)J recombination in cultured cells utilizes plasmid substrates [15,195] and expression vectors of the Rag1 and Rag2 proteins. The substrate plasmids bear an ampicillin resistance gene $(\mathrm{amp})$ and chloramphenicol resistance gene (cat) (Figure A1c). Since a transcription terminator sequence is inserted between the cat promoter and coding region, the substrate plasmids do not drive the expression of the cat gene in bacteria. Since this transcription terminator sequence is flanked by 12-RSS and 23-RSS, it can be removed by V(D)J recombination, allowing the expression of the cat gene in bacteria (Figure A1d). Depending on the orientation of the RSSs and coding sequences, the signal joint formation and the coding joint formation can be measured. Once the colonies are formed, they are counted to obtain the $\mathrm{V}(\mathrm{D}) \mathrm{J}$ recombination frequency and cultured for plasmid isolation and analysis. The frequency of $V(D) J$ recombination is measured by comparing the number of bacteria that are resistant to ampicillin alone and those that are resistant to both ampicillin and chloramphenicol. The fidelity of the signal joint formation can be examined by restriction enzyme digestion. Sanger sequencing of the plasmids around the junction will reveal the insertion of P-nucleotides or N-nucleotides and the deletion of nucleotides. 




(a)

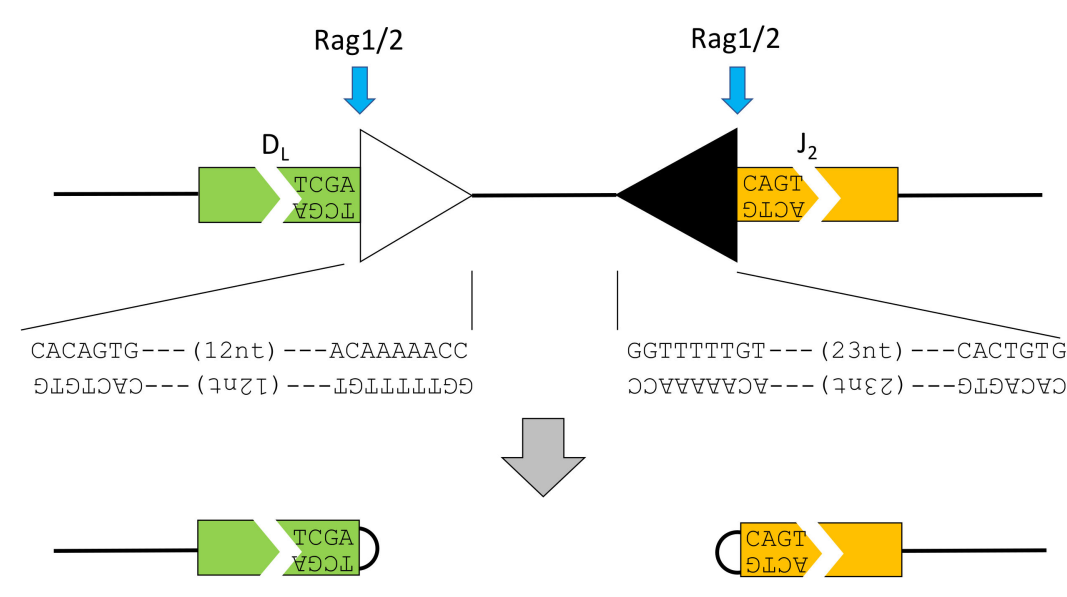

Artemis
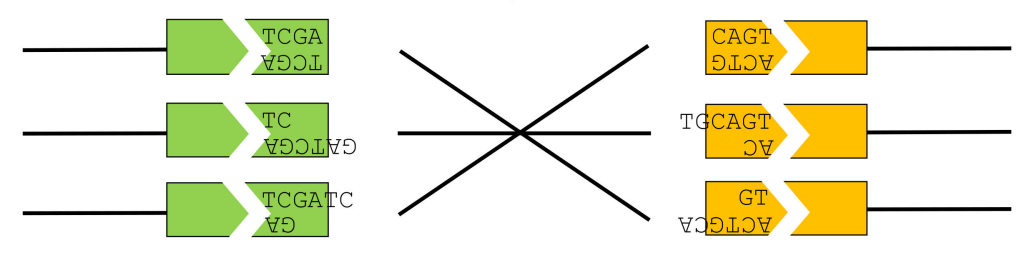

(c)
pJH200 (Signal Joint)

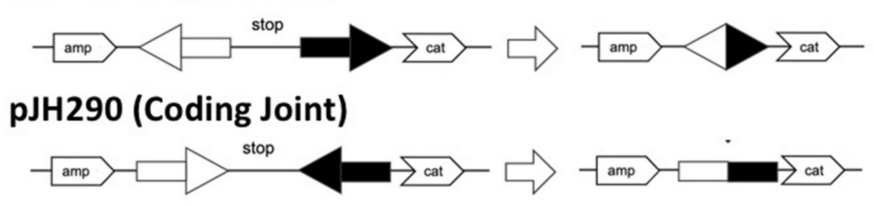

(b)
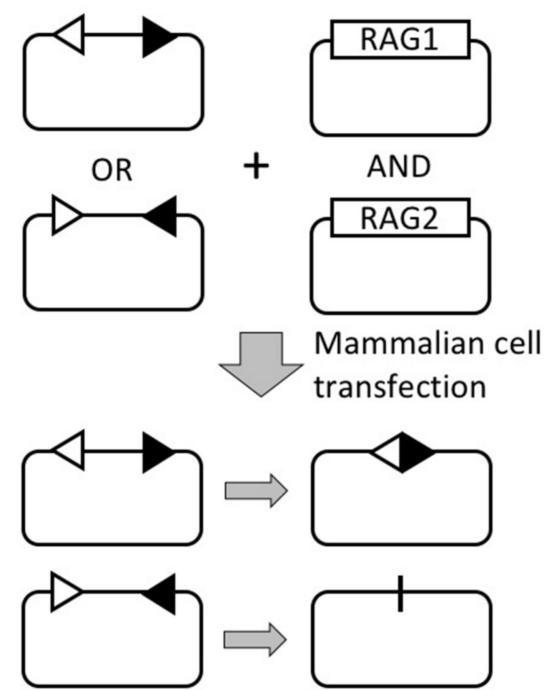

$V(D) J$ recombination

$\square$ E.coli transformation


(d)

Figure A1. Schematic diagram of V(D)J recombination and its measurements. (a) V(D)J recombination in the human immunoglobulin heavy chain locus. Red asterisks indicate the selected segments, which are joined together. (b) The recombination signal sequence (RSS) and its cleavage by Rag1 and Rag2, generating a blunt signal end and hairpin coding end. Opening the hairpin by Artemis can generate blunt, $5^{\prime}$-overhanging and $3^{\prime}$-overhanging ends, which can be joined in any combination. (c) Substrate plasmids for the measurements of the signal joint formation (pJH200) and coding joint formation (pJH290). (d) Outline of the V(D)J recombination assay.

\section{References}

1. Walker, A.I.; Hunt, T.; Jackson, R.J.; Anderson, C.W. Double-stranded DNA induces the phosphorylation of several proteins including the 90,000 mol. wt. heat-shock protein in animal cell extracts. EMBO J. 1985, 4, 139-145. [CrossRef] [PubMed]

2. Carter, T.; Vancurova, I.; Sun, I.; Lou, W.; DeLeon, S. A DNA-activated protein kinase from HeLa cell nuclei. Mol. Cell. Biol. 1990, 10, 6460-6471. [CrossRef] [PubMed]

3. Lees-Miller, S.P.; Chen, Y.R.; Anderson, C.W. Human cells contain a DNA-activated protein kinase that phosphorylates simian virus $40 \mathrm{~T}$ antigen, mouse p53, and the human Ku autoantigen. Mol. Cell. Biol. 1990, 10, 6472-6481. [CrossRef]

4. Dvir, A.; Stein, L.Y.; Calore, B.L.; Dynan, W.S. Purification and characterization of a template-associated protein kinase that phosphorylates RNA polymerase II. J. Biol. Chem. 1993, 268, 10440-10447. [CrossRef]

5. Gottlieb, T.M.; Jackson, S.P. The DNA-dependent protein kinase: Requirement for DNA ends and association with Ku antigen. Cell 1993, 72, 131-142. [CrossRef]

6. Mimori, T.; Akizuki, M.; Yamagata, H.; Inada, S.; Yoshida, S.; Homma, M. Characterization of a high molecular weight acidic nuclear protein recognized by autoantibodies in sera from patients with polymyositis-scleroderma overlap. J. Clin. Investig. 1981, 68, 611-620. [CrossRef] 
7. Mimori, T.; Hardin, J.A.; Steitz, J.A. Characterization of the DNA-binding protein antigen Ku recognized by autoantibodies from patients with rheumatic disorders. J. Biol. Chem. 1986, 261, 2274-2278. [CrossRef]

8. Mimori, T.; Hardin, J.A. Mechanism of interaction between Ku protein and DNA. J. Biol. Chem. 1986, 261, 10375-10379. [CrossRef]

9. Walker, J.R.; Corpina, R.A.; Goldberg, J. Structure of the Ku heterodimer bound to DNA and its implication for double-strand break repair. Nature 2001, 412, 607-614. [CrossRef]

10. Blunt, T.; Finnie, N.J.; Taccioli, G.E.; Smith, G.C.; Demengeot, J.; Gottlieb, T.M.; Mizuta, R.; Varghese, A.J.; Alt, F.W.; Jeggo, P.A. Defective DNA-dependent protein kinase activity is linked to $\mathrm{V}(\mathrm{D}) \mathrm{J}$ recombination and DNA repair defects associated with the murine scid mutation. Cell 1995, 80, 813-823. [CrossRef]

11. Kirchgessner, C.U.; Patil, C.K.; Evans, J.W.; Cuomo, C.A.; Fried, L.M.; Carter, T.; Oettinger, M.A.; Brown, J.M. DNA-dependent kinase (p350) as a candidate gene for the murine SCID defect. Science 1995, 267, 1178-1183. [CrossRef]

12. Peterson, S.R.; Kurimasa, A.; Oshimura, M.; Dynan, W.S.; Bradbury, E.M.; Chen, D.J. Loss of the catalytic subunit of the DNAdependent protein kinase in DNA double-strand-break-repair mutant mammalian cells. Proc. Natl. Acad. Sci. USA 1995, 92, 3171-3174. [CrossRef]

13. Bosma, G.C.; Custer, R.P.; Bosma, M.J. A severe combined immunodeficiency mutation in the mouse. Nature 1983, 301, 527-530. [CrossRef] [PubMed]

14. Malynn, B.A.; Blackwell, T.K.; Fulop, G.M.; Rathbun, G.A.; Furley, A.J.W.; Ferrier, P.; Heinke, L.B.; Phillips, R.A.; Yancopoulos, G.D.; Alt, F.W. The scid defect affects the final step of the immunoglobulin VDJ recombinase mechanism. Cell 1988, 54, 453-460. [CrossRef]

15. Lieber, M.R.; Hesse, J.E.; Lewis, S.; Bosma, G.C.; Rosenberg, N.; Mizuuchi, K.; Bosma, M.J.; Gellert, M. The defect in murine severe combined immune deficiency: Joining of signal sequences but not coding segments in V(D)J recombination. Cell 1988, 55, 7-16. [CrossRef]

16. Fulop, G.M.; Phillips, R.A. The scid mutation in mice causes general defect in DNA repair. Nature 1990, 347, 479-482. [CrossRef] [PubMed]

17. Lees-Miller, S.P.; Godbout, R.; Chan, D.W.; Weinfeld, M.; Day, R.S.; Barron, G.M.; Allalunis-Turner, J. Absence of p350 subunit of DNA-activated protein kinase from a radiosensitive human cell line. Science 1995, 267, 1183-1185. [CrossRef]

18. Taccioli, G.E.; Gottlieb, T.M.; Blunt, T.; Priestley, A.; Demengeot, J.; Mizuta, R.; Lehmann, A.R.; Alt, F.W.; Jackson, S.P.; Jeggo, P.A Ku80: Product of the XRCC5 gene and its role in DNA repair and V(D)J recombination. Science 1994, 265, 1442-1445. [CrossRef]

19. Smider, V.; Rathmell, W.K.; Lieber, M.R.; Chu, G. Restoration of X-ray resistance and V(D)J recombination in mutant cells by Ku cDNA. Science 1994, 266, 288-291. [CrossRef]

20. Matsumoto, Y.; Sharma, M.K. DNA-dependent protein kinase in DNA damage response: Three decades and beyond. J. Radiat. Cancer Res. 2020, 11, 123-134. [CrossRef]

21. Hartley, K.; Gell, D.; Smith, C.; Zhang, H.; Divecha, N.; Connelly, M.; Admon, A.; Lees-Miller, S.; Anderson, C.; Jackson, S. DNA-dependent protein kinase catalytic subunit: A relative of phosphatidylinositol 3-kinase and the ataxia telangiectasia gene product. Cell 1995, 82, 849-856. [CrossRef]

22. Savitsky, K.; Bar-Shira, A.; Gilad, S.; Rotman, G.; Ziv, Y.; Vanagaite, L.; Tagle, D.A.; Smith, S.; Uziel, T.; Sfez, S.; et al. A single ataxia telangiectasia gene with a product similar to PI-3 kinase. Science 1995, 268, 1749-1753. [CrossRef] [PubMed]

23. Hari, K.L.; Santerre, A.; Sekelsky, J.J.; McKim, K.S.; Boyd, J.B.; Hawley, R.S. The mei-41 gene of D. melanogaster is a structural and functional homolog of the human ataxia telangiectasia gene. Cell 1995, 82, 815-821. [CrossRef]

24. Greenwell, P.W.; Kronmal, S.L.; Porter, S.E.; Gassenhuber, J.; Obermaier, B.; Petes, T.D. TEL1, a gene involved in controlling telomere length in S. cerevisiae, is homologous to the human ataxia telangiectasia gene. Cell 1995, 82, 823-829. [CrossRef]

25. Morrow, D.M.; Tagle, D.A.; Shiloh, Y.; Collins, F.S.; Hieter, P. TEL1, an S. cerevisiae homolog of the human gene mutated in ataxia telangiectasia, is functionally related to the yeast checkpoint gene MEC1. Cell 1995, 82, 831-840. [CrossRef]

26. Paulovich, A.G.; Hartwell, L.H. A checkpoint regulates the rate of progression through S phase in S. cerevisiae in Response to DNA damage. Cell 1995, 82, 841-847. [CrossRef]

27. Bentley, N.J.; Holtzman, D.A.; Flaggs, G.; Keegan, K.S.; DeMaggio, A.; Ford, J.C.; Hoekstra, M.; Carr, A.M. The Schizosaccharomyces pombe rad3 checkpoint gene. EMBO J. 1996, 15, 6641-6651. [CrossRef]

28. Cimprich, K.A.; Shin, T.B.; Keith, C.T.; Schleiber, S.L. cDNA cloning and gene mapping of a candidate human cell cycle checkpoint protein. Proc. Natl. Acad. Sci. USA 1996, 93, 2850-2855. [CrossRef]

29. Denning, G.; Jamieson, L.; Maquat, L.E.; Thompson, E.A.; Fields, A.P. Cloning of a novel phosphatidylinositol kinase-related kinase: Characterization of the human SMG-1 RNA surveillance protein. J. Biol. Chem. 2001, 276, 22709-22714. [CrossRef]

30. Yamashita, A.; Ohnishi, T.; Kashima, I.; Taya, Y.; Ohno, S. Human SMG-1, a novel phosphatidylinositol 3-kinase-related protein kinase, associates with components of the mRNA surveillance complex and is involved in the regulation of nonsense-mediated mRNA decay. Genes Dev. 2001, 15, 2215-2228. [CrossRef]

31. Brown, E.J.; Albers, M.W.; Shin, T.B.; Ichikawa, K.; Keith, C.T.; Lane, W.S.; Schreiber, S.L. A mammalian protein targeted by G1-arresting rapamycin-receptor complex. Nature 1994, 369, 756-758. [CrossRef]

32. Sabatini, D.M.; Erdjument-Bromage, H.; Lui, M.; Tempst, P.; Snyder, S.H. RAFT1: A mammalian protein that binds to FKBP12 in a Rapamycin-dependent fashion and is homologous to yeast TORs. Cell 1994, 78, 35-43. [CrossRef]

33. McMahon, S.B.; Van Buskirk, H.A.; Dugan, K.A.; Copeland, T.D.; Cole, M.D. The novel ATM-related protein TRRAP is an essential cofactor for the c-Myc and E2F oncoproteins. Cell 1998, 94, 363-374. [CrossRef] 
34. Lees-Miller, S.P.; Anderson, C.W. The human double-stranded DNA-activated protein kinase phosphorylates the 90-kDa heatshock protein, hsp90 $\alpha$ at two NH2-terminal threonine residues. J. Biol. Chem. 1989, 264, 17275-17280. [CrossRef]

35. Lees-Miller, S.P.; Sakaguchi, K.; Ullrich, S.J.; Appella, E.; Anderson, C.W. Human DNA-activated protein kinase phosphorylates serines 15 and 37 in the amino-terminal transactivation domain of human p53. Mol. Cell. Biol. 1992, 12, 5041-5049. [CrossRef]

36. Banin, S.; Moyal, L.; Shieh, S.; Taya, Y.; Anderson, C.W.; Chessa, L.; Smorodinsky, N.I.; Prives, C.; Reiss, Y.; Shiloh, Y.; et al. Enhanced phosphorylation of p53 by ATM in response to DNA damage. Science 1998, 281, 1674-1677. [CrossRef] [PubMed]

37. Canman, C.E.; Lim, D.S.; Cimprich, K.A.; Taya, Y.; Tamai, K.; Sakaguchi, K.; Appella, E.; Kastan, M.B.; Siliciano, J.D. Activation of the ATM kinase by ionizing radiation and phosphorylation of p53. Science 1998, 281, 1677-1679. [CrossRef]

38. Girard, P.M.; Riballo, E.; Begg, A.C.; Waugh, A.; Jeggo, P.A. Nbs1 promotes ATM dependent phosphorylation events including those required for G1/S arrest. Oncogene 2002, 21, 4191-4199. [CrossRef] [PubMed]

39. Uziel, T.; Lerenthal, Y.; Moyal, L.; Andegeko, Y.; Mittelman, L.; Shiloh, Y. Requirement of the MRN complex for ATM activation by DNA damage. EMBO J. 2003, 22, 5612-5621. [CrossRef] [PubMed]

40. Zou, L.; Elledge, S.J. Sensing DNA damage through ATRIP recognition of RPA-ssDNA complexes. Science 2003, 300, 1542-1548. [CrossRef] [PubMed]

41. Falck, J.; Coates, J.; Jackson, S.P. Conserved modes of recruitment of ATM, ATR and DNA-PKcs to sites of DNA damage. Nature 2005, 434, 605-611. [CrossRef]

42. Zhao, B.; Rothenberg, E.; Ramsden, D.A.; Lieber, M.R. The molecular basis and disease relevance of non-homologous DNA end joining. Nat. Rev. Mol. Cell Biol. 2020, 21, 765-781. [CrossRef] [PubMed]

43. Pennisi, E. ENCODE Project writes eulogy for junk DNA. Science 2012, 6099, 1159-1161. [CrossRef] [PubMed]

44. Thacker, J.; Zdzienicka, M.Z. The mammalian XRCC genes: Their roles in DNA repair and genetic integrity. DNA Repair 2003, 2, 655-672. [CrossRef]

45. Li, Z.; Otevrel, T.; Gao, Y.; Cheng, H.; Seed, B.; Stamato, T.; Taccioli, G.E.; Alt, F.W. The XRCC4 gene encodes a novel protein involved in DNA double-strand break repair and V(D)J recombination. Cell 1995, 83, 1079-1089. [CrossRef]

46. Critchlow, S.; Bowater, R.; Jackson, S. Mammalian DNA double-strand break repair protein XRCC4 interacts with DNA ligase IV. Curr. Biol. 1997, 7, 588-598. [CrossRef]

47. Grawunder, U.; Wilm, M.; Wu, X.; Kulesza, P.; Wilson, T.; Mann, M.; Leiber, M.R. Activity of DNA ligase IV stimulated by complex formation with XRCC4 protein in mammalian cells. Nature 1997, 388, 492-495. [CrossRef]

48. Sado, K.; Ayusawa, D.; Enomoto, A.; Suganuma, T.; Oshimura, M.; Sato, K.; Koyama, H. Identification of a mutated DNA ligase IV gene in the X-ray-hypersensitive mutant SX10 of mouse FM3A cells. J. Biol. Chem. 2001, 276, 9742-9748. [CrossRef]

49. Riballo, E.; Critchlow, S.E.; Teo, S.H.; Doherty, A.J.; Priestley, A.; Broughton, B.; Kysela, B.; Beamish, H.; Plowman, N.; Arlett, C.F.; et al. Identification of a defect in DNA ligase IV in a radiosensitive leukemia patient. Curr. Biol. 1999, 9, 699-702. [CrossRef]

50. Moshous, D.; Callebaut, I.; de Chasseval, R.; Corneo, B.; Cavazzana-Calvo, M.; Le Deist, F.; Tezcan, I.; Sanal, O.; Bertrand, Y.; Philippe, N.; et al. Artemis, a novel DNA double-strand break repair/V(D)J recombination protein, is mutated in human severe combined immune deficiency. Cell 2001, 105, 177-186. [CrossRef]

51. Ma, Y.; Pannicke, U.; Schwarz, K.; Lieber, M.R. Hairpin opening and overhang processing by an Artemis/DNA-dependent protein kinase complex in nonhomologous end joining and V(D)J recombination. Cell 2002, 108, 781-794. [CrossRef]

52. Buck, D.; Malivert, L.; de Chasseval, R.; Barraud, A.; Fondanèche, M.C.; Sanal, O.; Plebani, A.; Stéphan, J.L.; Hufnagel, M.; le Deist, F.; et al. Cernunnos.; a novel nonhomologous end-joining factor.; is mutated in human immunodeficiency with microcephaly. Cell 2006, 124, 287-299. [CrossRef]

53. Ahnesorg, P.; Smith, P.; Jackson, S.P. XLF interacts with the XRCC4-DNA ligase IV complex to promote DNA nonhomologous end-joining. Cell 2006, 124, 301-313. [CrossRef] [PubMed]

54. Callebaut, I.; Malivert, L.; Fischer, A.; Mornon, J.P.; Revy, P.; de Villartay, J.P. Cernunnos interacts with the XRCC4 x DNA-ligase IV complex and is homologous to the yeast nonhomologous end-joining factor Nej1. J. Biol. Chem. 2006, 281, 13857-13860. [CrossRef]

55. Gu, J.; Lu, H.; Tsai, A.G.; Schwarz, K.; Lieber, M.R. Single-stranded DNA ligation and XLF-stimulated incompatible DNA end ligation by the XRCC4-DNA ligase IV complex: Influence of terminal DNA sequence. Nucleic Acids Res. 2007, 35, 5755-5762. [CrossRef]

56. Tsai, C.J.; Kim, S.A.; Chu, G. Cernunnos/XLF promotes the ligation of mismatched and noncohesive DNA ends. Proc. Natl. Acad. Sci. USA 2007, 104, 7851-7856. [CrossRef] [PubMed]

57. Hammel, M.; Yu, Y.; Fang, S.; Lees-Miller, S.P.; Tainer, J.A. XLF regulates filament architecture of the XRCC4-ligase IV complex. Structure 2010, 18, 1431-1442. [CrossRef] [PubMed]

58. Ropars, V.; Drevet, P.; Legrand, P.; Baconnais, S.; Amram, J.; Faure, G.; Márquez, J.A.; Pietrement, O.; Guerois, R.; Callebaut, I.; et al. Structural characterization of filaments formed by human Xrcc4-Cernunnos/XLF complex involved in nonhomologous DNA end-joining. Proc. Natl. Acad. Sci. USA 2011, 108, 12663-12668. [CrossRef] [PubMed]

59. Andres, S.N.; Vergnes, A.; Ristic, D.; Wyman, C.; Modesti, M.; Junop, M. A human XRCC4-XLF complex bridges DNA. Nucleic Acids Res. 2012, 40, 1868-1878. [CrossRef]

60. Mahaney, B.L.; Hammel, M.; Meek, K.; Tainer, J.A.; Lees-Miller, S.P. XRCC4 and XLF form long helical protein filaments suitable for DNA end protection and alignment to facilitate DNA double strand break repair. Biochem. Cell Biol. 2013, 91, 31-41. [CrossRef] 
61. Ochi, T.; Blackford, A.N.; Coates, J.; Jhujh, S.; Mehmood, S.; Tamura, N.; Travers, J.; Wu, Q.; Draviam, V.M.; Robinson, C.V.; et al. DNA repair. PAXX, a paralog of XRCC4 and XLF, interacts with Ku to promote DNA double-strand break repair. Science 2015, 347, 185-188. [CrossRef] [PubMed]

62. Xing, M.; Yang, M.; Huo, W.; Feng, F.; Wei, L.; Jiang, W.; Ning, S.; Yan, Z.; Li, W.; Wang, Q.; et al. Interactome analysis identifies a new paralogue of XRCC4 in non-homologous end joining DNA repair pathway. Nat. Commun. 2015, 6, 6233. [CrossRef]

63. Craxton, A.; Somers, J.; Munnur, D.; Jukes-Jones, R.; Cain, K.; Malewicz, M. XLS (c9orf142) is a new component of mammalian DNA double-stranded break repair. Cell Death Diff. 2015, 22, 890-897. [CrossRef] [PubMed]

64. Kienker, L.J.; Shin, E.K.; Meek, K. Both V(D)J recombination and radioresistance require DNA-PK kinase activity, though minimal levels suffice for V(D)J recombination. Nucleic Acids Res. 2000, 28, 2752-2761. [CrossRef] [PubMed]

65. Kurimasa, A.; Kumano, S.; Boubnov, N.; Story, M.; Tung, C.; Peterson, S.; Chen, D.J. Requirement for the kinase activity of human DNA-dependent protein kinase catalytic subunit in DNA strand break rejoining. Mol. Cell. Biol. 1999, 19, 3877-3884. [CrossRef] [PubMed]

66. Blunt, T.; Gell, D.; Fox, M.; Taccioli, G.E.; Lehmann, A.R.; Jackson, S.P.; Jeggo, P.A. Identification of a nonsense mutation in the carboxyl-terminal region of DNA-dependent protein kinase catalytic subunit in the scid mouse. Proc. Natl. Acad. Sci. USA 1996, 93, 10285-10290. [CrossRef]

67. Danska, J.S.; Holland, D.P.; Mariathasan, S.; Williams, K.M.; Guidos, C.J. Biochemical and genetic defects in the DNA-dependent protein kinase in murine scid lymphocytes. Mol. Cell. Biol. 1996, 16, 5507-5517. [CrossRef]

68. Araki, R.; Fujimori, A.; Hamatani, K.; Mita, K.; Saito, T.; Mori, M.; Fukumura, R.; Morimyo, M.; Muto, M.; Itoh, M.; et al. Nonsense mutation at Tyr-4046 in the DNA-dependent protein kinase catalytic subunit of severe combined immune deficiency mice. Proc. Natl. Acad. Sci. USA 1997, 94, 2438-2443. [CrossRef] [PubMed]

69. Priestley, A.; Beamish, H.J.; Singleton, B.K.; Blunt, T.; Jeggo, P.A.; Gell, D.; Smith, G.C.M.; Jackson, S.P.; Amatucci, A.G. Molecular and biochemical characterisation of DNA-dependent protein kinase-defective rodent mutant irs-20. Nucleic Acids Res. 1998, 26, 1965-1973. [CrossRef]

70. Anderson, C.W.; Dunn, J.J.; Freimuth, P.I.; Galloway, A.M.; Allalunis-Turner, M.J. Frameshift mutation in PRKDC, the gene for DNA-PKcs, in the DNA repair-defective, human, glioma-derived cell line M059J. Radiat. Res. 2001, 156, 2-9. [CrossRef]

71. Peterson, S.R.; Stackhouse, M.; Waltman, M.J.; Chen, F.; Sato, K.; Chen, D.J. Characterization of two DNA double-stranded break repair-deficient cell lines that express inactive DNA-dependent protein kinase catalytic subunits. J. Biol. Chem. 1997, 272, 10227-10231. [CrossRef] [PubMed]

72. Fukumura, R.; Araki, R.; Fujimori, A.; Mori, M.; Saito, T.; Watanabe, F.; Sarashi, M.; Itsukaichi, H.; Eguchi-Kasai, K.; Sato, K.; et al. Murine cell line SX9 bearing a mutation in the DNA-PKcs gene exhibits aberrant V(D)J recombination not only in the coding joint but also in the signal joint. J. Biol. Chem. 1998, 273, 13058-13064. [CrossRef]

73. Errami, A.; He, D.M.; Friedl, A.A.; Overkamp, W.J.; Morolli, B.; Hendrickson, E.A.; Eckardt-Schupp, F.; Oshimura, M.; Lohman, P.H.; Jackson, S.P.; et al. XR-C1, a new CHO cell mutant which is defective in DNA-PKcs, is impaired in both V(D)J coding and signal joint formation. Nucleic Acids Res. 1998, 26, 3146-3153. [CrossRef]

74. Errami, A.; Overkamp, W.J.; He, D.M.; Friedl, A.A.; Gell, D.A.; Eckardt-Schupp, F.; Jackson, S.P.; Hendrickson, E.A.; Lohman, P.H.; Zdzienicka, M.Z. A new X-ray sensitive CHO cell mutant of ionizing radiation group 7, XR-C2, that is defective in DSB repair but has only a mild defect in $\mathrm{V}(\mathrm{D}) \mathrm{J}$ recombination. Mutat. Res. 2000, 461, 59-69. [CrossRef]

75. Woods, T.; Wang, W.; Convery, E.; Errami, A.; Zdzienicka, M.Z.; Meek, K. A single amino acid substitution in DNA-PKcs explains the novel phenotype of the CHO mutant, XR-C2. Nucleic Acids Res. 2002, 30, 5120-5128. [CrossRef] [PubMed]

76. Fukushima, T.; Takata, M.; Morrison, C.; Araki, R.; Fujimori, A.; Abe, M.; Tatsumi, K.; Jasin, M.; Dhar, P.K.; Sonoda, E.; et al. Genetic analysis of the DNA-dependent protein kinase reveals an inhibitory role of Ku in late S-G2 phase DNA double-strand break repair. J. Biol. Chem. 2001, 276, 44413-44418. [CrossRef] [PubMed]

77. Ruis, B.L.; Fattah, K.R.; Hendrickson, E.A. The catalytic subunit of DNA-dependent protein kinase regulates proliferation, telomere length, and genomic stability in human somatic cells. Mol. Cell. Biol. 2008, 28, 6182-6195. [CrossRef]

78. Keka, I.S.; Mohiuddin; Maede, Y.; Rahman, M.M.; Sakuma, T.; Honma, M.; Yamamoto, T.; Takeda, S.; Sasanuma, H. Smarcal1 promotes double-strand-break repair by nonhomologous end-joining. Nucleic Acids Res. 2015, 43, 6359-6372. [CrossRef]

79. Xing, M.; Oksenych, V. Genetic interaction between DNA repair factors PAXX, XLF, XRCC4 and DNA-PKcs in human cells. FEBS Open Bio 2019, 9, 1315-1326. [CrossRef]

80. Soleimani, F.; Babaei, E.; Feizi, M.A.H.; Fathi, F. CRISPR-Cas9-mediated knockout of the Prkdc in mouse embryonic stem cells leads to the modulation of the expression of pluripotency genes. J. Cell Physiol. 2020, 235, 3994-4000. [CrossRef] [PubMed]

81. Douglas, P.; Ye, R.; Radhamani, S.; Cobban, A.; Jenkins, N.P.; Bartlett, E.; Roveredo, J.; Kettenbach, A.N.; Lees-Miller, S.P. Nocodazole-Induced Expression and Phosphorylation of Anillin and Other Mitotic Proteins Are Decreased in DNA-Dependent Protein Kinase Catalytic Subunit-Deficient Cells and Rescued by Inhibition of the Anaphase-Promoting Complex/Cyclosome with proTAME but Not Apcin. Mol. Cell. Biol. 2020, 40, e00191-19.

82. Taccioli, G.E.; Rathbun, G.; Stamato, T.; Jeggo, P.A.; Alt, F.W. Impairment of V(D)J recombination in double-strand break repair mutants. Science 1993, 260, 207-210. [CrossRef]

83. Bosma, G.C.; Fried, M.; Custer, R.P.; Carroll, A.; Gibson, D.M.; Bosma, M.J. Evidence of functional lymphocytes in some (leaky) scid mice. J. Exp. Med. 1988, 167, 1016-1033. [CrossRef] [PubMed] 
84. Taccioli, G.E.; Amatucci, A.G.; Beamish, H.J.; Gell, D.; Xiang, X.H.; Torres, A.M.I.; Priestley, A.; Jackson, S.P.; Marshak, R.A.; Jeggo, P.A.; et al. Targeted disruption of the catalytic subunit of the DNA-PK gene in mice confers severe combined immunodeficiency and radiosensitivity. Immunity 1998, 9, 355-366. [CrossRef]

85. Gao, Y.; Chaudhuri, J.; Zhu, C.; Davidson, L.; Weaver, D.T.; Alt, F.W. A targeted DNA-PKcs-null mutation reveals DNA-PKindependent functions for KU in V(D)J recombination. Immunity 1998, 9, 367-376. [CrossRef]

86. Kurimasa, A.; Ouyang, H.; Dong, L.J.; Wang, S.; Li, X.; Cordon-Cardo, C.; Chen, D.J.; Li, G.C. Catalytic subunit of DNA-dependent protein kinase: Impact on lymphocyte development and tumorigenesis. Proc. Natl. Acad. Sci. USA 1999, 96, 1403-1438. [CrossRef]

87. Jhappan, C.; Morse, H.C.; Fleischmann, R.D.; Gottesman, M.M.; Merlino, G. DNA-PKcs: A T-cell tumour suppressor encoded at the mouse scid locus. Nat. Genet. 1997, 17, 483-486. [CrossRef] [PubMed]

88. Bogue, M.A.; Jhappan, C.; Roth, D.B. Analysis of variable (diversity) joining recombination in DNAdependent protein kinase (DNA-PK)-deficient mice reveals DNA-PK-independent pathways for both signal and coding joint formation. Proc. Natl. Acad. Sci. USA 1998, 95, 15559-15564. [CrossRef]

89. Jiang, W.; Crowe, J.L.; Liu, X.; Nakajima, S.; Wang, Y.; Li, C.; Lee, B.J.; Dubois, R.L.; Liu, C.; Yu, X.; et al. Differential phosphorylation of DNA-PKcs regulates the interplay between end-processing and end-ligation during nonhomologous endjoining. Mol. Cell 2015, 58, 172-185. [CrossRef]

90. Zhang, S.; Yajima, H.; Huynh, H.; Zheng, J.; Callen, N.; Chen, H.-T.; Wong, N.; Bunting, S.; Lin, Y.-F.; Li, M.; et al. Congenital bone marrow failure in DNA-PKcs mutant mice associated with deficiencies in DNA repair. J. Cell Biol. 2011, 193, 295-305. [CrossRef]

91. Okayasu, R.; Suetomi, K.; Yu, Y.; Silver, A.; Bedford, J.S.; Cox, R.; Ullrich, R.L. A deficiency in DNA repair and DNA-PKcs expression in the radiosensitive BALB/c mouse. Cancer Res. 2000,60, 4342-4345.

92. Yu, Y.; Okayasu, R.; Weil, M.M.; Silver, A.; McCarthy, M.; Zabriskie, R.; Long, S.; Cox, R.; Ullrich, R.L. Elevated breast cancer risk in irradiated BALB/c mice associates with unique functional polymorphism of the Prkdc (DNA-dependent protein kinase catalytic subunit) gene. Cancer Res. 2001, 61, 1820-1824.

93. Mori, N.; Matsumoto, Y.; Okumoto, M.; Suzuki, N.; Yamate, J. Variations in Prkdc encoding the catalytic subunit of DNAdependent protein kinase (DNA-PKcs) and susceptibility to radiation-induced apoptosis and lymphomagenesis. Oncogene 2001, 20,3609-3619. [CrossRef]

94. McGuire, T.C.; Poppie, M.J. Hypogammaglobulinemia and thymic hypoplasia in horses: A primary combined immunodeficiency disorder. Infect. Immun. 1973, 8, 272-277. [CrossRef] [PubMed]

95. Wiler, R.; Leber, R.; Moore, B.B.; VanDyk, L.F.; Perryman, L.E.; Meek, K. Equine severe combined immunodeficiency: A defect in V(D)J recombination and DNA-dependent protein kinase activity. Proc. Natl. Acad. Sci. USA 1995, 92, 11485-11489. [CrossRef] [PubMed]

96. Shin, E.K.; Perryman, L.E.; Meek, K. A kinase-negative mutation of DNA-PK(CS) in equine SCID results in defective coding and signal joint formation. J. Immunol. 1997, 158, 3565-3569. [PubMed]

97. Meek, K.; Kienker, L.; Dallas, C.; Wang, W.; Dark, M.J.; Venta, P.J.; Huie, M.L.; Hirschhorn, R.; Bell, T. SCID in Jack Russell terriers: A new animal model of DNA-PKcs deficiency. J. Immunol. 2001, 167, 2142-2150. [CrossRef] [PubMed]

98. Ding, Q.; Bramble, L.; Yuzbasiyan-Gurkan, V.; Bell, T.; Meek, K. DNA-PKcs mutations in dogs and horses: Allele frequency and association with neoplasia. Gene 2002, 283, 263-269. [CrossRef]

99. Mashimo, T.; Takizawa, A.; Kobayashi, J.; Kunihiro, Y.; Yoshimi, K.; Ishida, S.; Tanabe, K.; Yanagi, A.; Tachibana, A.; Hirose, J.; et al. Generation and characterization of severe combined immunodeficiency rats. Cell Rep. 2012, 2, 685-694. [CrossRef] [PubMed]

100. Jung, I.H.; Chung, Y.Y.; Jung, D.E.; Kim, Y.J.; Kim Do, H.; Kim, K.S.; Park, S.W. Impaired Lymphocytes Development and Xenotransplantation of Gastrointestinal Tumor Cells in Prkdc-Null SCID Zebrafish Model. Neoplasia 2016, 18, 468-479. [CrossRef] [PubMed]

101. Moore, J.C.; Tang, Q.; Yordán, N.T.; Moore, F.E.; Garcia, E.G.; Lobbardi, R.; Ramakrishnan, A.; Marvin, D.L.; Anselmo, A.; Sadreyev, R.I.; et al. Single-cell imaging of normal and malignant cell engraftment into optically clear prkdc-null SCID zebrafish. J. Exp. Med. 2016, 213, 2575-2589. [CrossRef]

102. Zhu, C.; Bogue, M.A.; Lim, D.S.; Hasty, P.; Roth, D.B. Ku86-deficient mice exhibit severe combined immunodeficiency and defective processing of V(D)J recombination intermediates. Cell 1996, 86, 379-389. [CrossRef]

103. Nussenzweig, A.; Chen, C.; da Costa Soares, V.; Sanchez, M.; Sokol, K.; Nussenzweig, M.C.; Li, G.C. Requirement for Ku80 in growth and immunoglobulin V(D)J recombination. Nature 1996, 382, 551-555. [CrossRef]

104. Ouyang, H.; Nussenzweig, A.; Kurimasa, A.; Soares, V.C.; Li, X.; Cordon-Cardo, C.; Li, W.H.; Cheong, N.; Nussenzweig, M.; Iliakis, G.; et al. Ku70 is required for DNA repair but not for T cell antigen receptor gene recombination in vivo. J. Exp. Med. 1997, 186, 921-929. [CrossRef]

105. Gu, Y.; Seidl, K.J.; Rathbun, G.A.; Zhu, C.; Manis, J.P.; van der Stoep, N.; Davidson, L.; Cheng, H.L.; Sekiguchi, J.M.; Frank, K.; et al. Growth retardation and leaky SCID phenotype of Ku70-deficient mice. Immunity 1997, 7, 653-665. [CrossRef]

106. Li, G.C.; Ouyang, H.; Li, X.; Nagasawa, H.; Little, J.B.; Chen, D.J.; Ling, C.C.; Fuks, Z.; Cordon-Cardo, C. Ku70: A candidate tumor suppressor gene for murine T cell lymphoma. Mol. Cell 1998, 2, 1-8. [CrossRef]

107. Gu, Y.; Sekiguchi, J.; Gao, Y.; Dikkes, P.; Frank, K.; Ferguson, D.; Hasty, P.; Chun, J.; Alt, F.W. Defective embryonic neurogenesis in Ku-deficient but not DNA-dependent protein kinase catalytic subunit-deficient mice. Proc. Natl. Acad. Sci. USA 2000, 97, 2668-2673. [CrossRef] [PubMed] 
108. Frank, K.M.; Sekiguchi, J.M.; Seidl, K.J.; Swat, W.; Rathbun, G.A.; Cheng, H.L.; Davidson, L.; Kangaloo, L.; Alt, F.W. Late embryonic lethality and impaired V(D)J recombination in mice lacking DNA ligase IV. Nature 1998, 396, 173-177. [CrossRef] [PubMed]

109. Barnes, D.E.; Stamp, G.; Rosewell, I.; Denzel, A.; Lindahl, T. Targeted disruption of the gene encoding DNA ligase IV leads to lethality in embryonic mice. Curr. Biol. 1998, 8, 1395-1398. [CrossRef]

110. Gao, Y.; Sun, Y.; Frank, K.M.; Dikkes, P.; Fujiwara, Y.; Seidl, K.J.; Sekiguchi, J.M.; Rathbun, G.A.; Swat, W.; Wang, J.; et al. A critical role for DNA end-joining proteins in both lymphogenesis and neurogenesis. Cell 1998, 95, 891-902. [CrossRef]

111. Rooney, S.; Sekiguchi, J.; Zhu, C.; Cheng, H.L.; Manis, J.; Whitlow, S.; DeVido, J.; Foy, D.; Chaudhuri, J.; Lombard, D.; et al. Leaky Scid phenotype associated with defective V(D)J coding end processing in Artemis-deficient mice. Mol. Cell 2002, 10, 1379-1390. [CrossRef]

112. Li, G.; Alt, F.W.; Cheng, H.L.; Brush, J.W.; Goff, P.H.; Murphy, M.M.; Franco, S.; Zhang, Y.; Zha, S. Lymphocyte-specific compensation for XLF/cernunnos end-joining functions in V(D)J recombination. Mol. Cell 2008, 31, 631-640. [CrossRef]

113. Zha, S.; Guo, C.; Boboila, C.; Oksenych, V.; Cheng, H.L.; Zhang, Y.; Wesemann, D.R.; Yuen, G.; Patel, H.; Goff, P.H.; et al. ATM damage response and XLF repair factor are functionally redundant in joining DNA breaks. Nature 2011, 469, 250-254. [CrossRef]

114. Oksenych, V.; Kumar, V.; Liu, X.; Guo, C.; Schwer, B.; Zha, S.; Alt, F.W. Functional redundancy between the XLF and DNA-PKcs DNA repair factors in V(D)J recombination and nonhomologous DNA end joining. Proc. Natl. Acad. Sci. USA 2013, 110, 2234-2239. [CrossRef]

115. Kumar, V.; Alt, F.W.; Frock, R.L. PAXX and XLF DNA repair factors are functionally redundant in joining DNA breaks in a G1-arrested progenitor B-cell line. Proc. Natl. Acad. Sci. USA 2016, 113, 10619-10624. [CrossRef] [PubMed]

116. Balmus, G.; Barros, A.C.; Wijnhoven, P.W.; Lescale, C.; Hasse, H.L.; Boroviak, K.; le Sage, C.; Doe, B.; Speak, A.O.; Galli, A.; et al. Synthetic lethality between PAXX and XLF in mammalian development. Genes Dev. 2016, 30, 2152-2157. [CrossRef] [PubMed]

117. Van der Burg, M.; Ijspeert, H.; Verkaik, N.S.; Turul, T.; Wiegant, W.W.; Morotomi-Yano, K.; Mari, P.O.; Tezcan, I.; Chen, D.J.; Zdzienicka, M.Z.; et al. A DNA-PKcs mutation in a radiosensitive T-B- SCID patient inhibits Artemis activation and nonhomologous end-joining. J. Clin. Investig. 2009, 119, 91-98. [CrossRef]

118. Mathieu, A.L.; Verronese, E.; Rice, G.I.; Fouyssac, F.; Bertrand, Y.; Picard, C.; Chansel, M.; Walter, J.E.; Notarangelo, L.D.; Butte, M.J.; et al. PRKDC mutations associated with immunodeficiency, granuloma, and autoimmune regulator-dependent autoimmunity. J. Allergy Clin. Immunol. 2015, 135, 1578-1588.e5. [CrossRef]

119. Esenboga, S.; Akal, C.; Karaatmaca, B.; Erman, B.; Dogan, S.; Orhan, D.; Boztug, K.; Ayvaz, D.; Tezcan, İ. Two siblings with PRKDC defect who presented with cutaneous granulomas and review of the literature. Clin. Immunol. 2018, 197, 1-5. [CrossRef] [PubMed]

120. Woodbine, L.; Neal, J.A.; Sasi, N.K.; Shimada, M.; Deem, K.; Coleman, H.; Dobyns, W.B.; Ogi, T.; Meek, K.; Davies, E.G.; et al. PRKDC mutations in a SCID patient with profound neurological abnormalities. J. Clin. Investig. 2013, 123, 2969-2980. [CrossRef] [PubMed]

121. Li, G.; Nelsen, C.; Hendrickson, E.A. Ku86 is essential in human somatic cells. Proc. Natl. Acad. Sci. USA 2002, 99, 832-837. [CrossRef]

122. Fattah, F.J.; Lichter, N.F.; Fattah, K.R.; Oh, S.; Hendrickson, E.A. Ku70, an essential gene, modulates the frequency of rAAVmediated gene targeting in human somatic cells. Proc. Natl. Acad. Sci. USA 2008, 105, 8703-8708. [CrossRef]

123. Wang, Y.; Ghosh, G.; Hendrickson, E.A. Ku86 represses lethal telomere deletion events in human somatic cells. Proc. Natl. Acad. Sci. USA 2009, 106, 12430-12435. [CrossRef] [PubMed]

124. Fattah, F.; Lee, E.H.; Weisensel, N.; Wang, Y.; Lichter, N.; Hendrickson, E.A. Ku regulates the non-homologous end joining pathway choice of DNA double-strand break repair in human somatic cells. PLoS Genet. 2010, 6, e1000855. [CrossRef]

125. Myung, K.; Ghosh, G.; Fattah, F.J.; Li, G.; Kim, H.; Dutia, A.; Pak, E.; Smith, S.; Hendrickson, E.A. Regulation of telomere length and suppression of genomic instability in human somatic cells by Ku86. Mol. Cell. Biol. 2004, 24, 5050-5059. [CrossRef] [PubMed]

126. Smith, J.; Riballo, E.; Kysela, B.; Baldeyron, C.; Manolis, K.; Masson, C.; Lieber, M.R.; Papadopoulo, D.; Jeggo, P. Impact of DNA ligase IV on the fidelity of end joining in human cells. Nucleic Acids Res. 2003, 31, 2157-2167. [CrossRef]

127. So, S.; Adachi, N.; Lieber, M.R.; Koyama, H. Genetic interactions between BLM and DNA ligase IV in human cells. J. Biol. Chem. 2004, 279, 55433-55442. [CrossRef] [PubMed]

128. Katsube, T.; Mori, M.; Tsuji, H.; Shiomi, T.; Shiomi, N.; Onoda, M. Differences in sensitivity to DNA-damaging Agents between XRCC4- and Artemis-deficient human cells. J. Radiat. Res. 2011, 52, 415-424. [CrossRef]

129. Oh, S.; Wang, Y.; Zimbric, J.; Hendrickson, E.A. Human LIGIV is synthetically lethal with the loss of Rad54B-dependent recombination and is required for certain chromosome fusion events induced by telomere dysfunction. Nucleic Acids Res. 2013, 41, 1734-1749. [CrossRef]

130. Ruis, B.; Molan, A.; Takasugi, T.; Hendrickson, E.A. Absence of XRCC4 and its paralogs in human cells reveal differences in outcomes for DNA repair and V(D)J recombination. DNA Repair 2020, 85, 102738. [CrossRef]

131. Barlow, C.; Hirotsune, S.; Paylor, R.; Liyanage, M.; Eckhaus, M.; Collins, F.; Shiloh, Y.; Crawley, J.N.; Ried, T.; Tagle, D.; et al. Atm-deficient mice: A paradigm of ataxia telangiectasia. Cell 1996, 86, 159-171. [CrossRef]

132. Xu, Y.; Ashley, T.; Brainerd, E.E.; Bronson, R.T.; Meyn, M.S.; Baltimore, D. Targeted disruption of ATM leads to growth retardation, chromosomal fragmentation during meiosis, immune defects, and thymic lymphoma. Genes Dev. 1996, 10, 2411-2422. [CrossRef] 
133. Gurley, K.E.; Kemp, C.J. Synthetic lethality between mutation in Atm and DNA-PKcs during murine embryogenesis. Curr. Biol. 2001, 11, 191-194. [CrossRef]

134. Sekiguchi, J.; Ferguson, D.O.; Chen, H.T.; Yang, E.M.; Earle, J.; Frank, K.; Whitlow, S.; Gu, Y.; Xu, Y.; Nussenzweig, A.; et al. Genetic interactions between ATM and the nonhomologous end-joining factors in genomic stability and development. Proc. Natl. Acad. Sci. USA 2001, 98, 3243-3248. [CrossRef] [PubMed]

135. Enriquez-Rios, V.; Dumitrache, L.C.; Downing, S.M.; Li, Y.; Brown, E.J.; Russell, H.R.; McKinnon, P.J. DNA-PKcs, ATM, and ATR interplay maintains genome integrity during neurogenesis. J. Neurosci. 2017, 37, 893-905. [CrossRef] [PubMed]

136. Hsieh, C.L.; Arlett, C.F.; Lieber, M.R. V(D)J recombination in ataxia telangiectasia, Bloom's syndrome, and a DNA ligase I-associated immunodeficiency disorder. J. Biol. Chem. 1993, 268, 20105-20109. [CrossRef]

137. Bredemeyer, A.L.; Sharma, G.G.; Huang, C.Y.; Helmink, B.A.; Walker, L.M.; Khor, K.C.; Nuskey, B.; Sullivan, K.E.; Pandita, T.K.; Bassing, C.H.; et al. ATM stabilizes DNA double-strand-break complexes during V(D)J recombination. Nature 2006, 442, 466-470. [CrossRef]

138. Vacchio, M.S.; Olaru, A.; Livak, F; Hodes, R.J. ATM deficiency impairs thymocyte maturation because of defective resolution of T cell receptor $\alpha$ locus coding end breaks. Proc. Natl. Acad. Sci. USA 2007, 104, 6323-6328. [CrossRef]

139. Huang, C.Y.; Sharma, G.G.; Walker, L.M.; Bassing, C.H.; Pandita, T.K.; Sleckman, B.P. Defects in coding joint formation in vivo in developing ATM-deficient B and T lymphocytes. J. Exp. Med. 2007, 204, 1371-1381. [CrossRef]

140. Gapud, E.J.; Dorsett, Y.; Yi, B.; Callen, E.; Bredemeyer, A.; Mahowald, G.K.; Omi, K.Q.; Walker, L.M.; Bednarski, J.J.; McKinnon, P.J.; et al. Ataxia telangiectasia mutated (Atm) and DNA-PKcs kinases have overlapping activities during chromosomal signal joint formation. Proc. Natl. Acad. Sci. USA 2011, 108, 2022-2027. [CrossRef]

141. Zha, S.; Jiang, W.; Fujiwara, Y.; Patel, H.; Goff, P.H.; Brush, J.W.; Dubois, R.L.; Alt, F.W. Ataxia telangiectasia-mutated protein and DNA-dependent protein kinase have complementary V(D)J recombination functions. Proc. Natl. Acad. Sci. USA 2011, 108, 2028-2033. [CrossRef] [PubMed]

142. Ma, Y.; Pannicke, U.; Lu, H.; Niewolik, D.; Schwarz, K.; Lieber, M.R. The DNA-dependent protein kinase catalytic subunit phosphorylation sites in human Artemis. J. Biol. Chem. 2005, 280, 33839-33846. [CrossRef] [PubMed]

143. Poinsignon, C.; de Chasseval, R.; Soubeyrand, S.; Moshous, D.; Fischer, A.; Haché, R.J.; de Villartay, J.-P. Phosphorylation of Artemis following irradiation-induced DNA damage. Eur. J. Immunol. 2004, 34, 3146-3155. [CrossRef]

144. Goodarzi, A.A.; Yu, Y.; Riballo, E.; Douglas, P.; Walker, S.A.; Ye, R.; Härer, C.; Marchetti, C.; Morrice, N.; Jeggo, P.A.; et al. DNA-PK autophosphorylation facilitates Artemis endonuclease activity. EMBO J. 2006, 25, 3880-3889. [CrossRef] [PubMed]

145. Zhang, X.; Succi, J.; Feng, Z.; Prithivirajsingh, S.; Story, M.D.; Legerski, R.J. Artemis is a phosphorylation target of ATM and ATR and is involved in the G2/M DNA damage checkpoint response. Mol. Cell. Biol. 2004, 24, 9207-9220. [CrossRef] [PubMed]

146. Riballo, E.; Kühne, M.; Rief, N.; Doherty, A.; Smith, G.C.; Recio, M.J.; Reis, C.; Dahm, K.; Fricke, A.; Krempler, A.; et al. A pathway of double-strand break rejoining dependent upon ATM, Artemis, and proteins locating to $\gamma-\mathrm{H} 2 \mathrm{AX}$ foci. Mol. Cell 2004, 16, 715-724. [CrossRef]

147. Chen, L.; Morio, T.; Minegishi, Y.; Nakada, S.; Nagasawa, M.; Komatsu, K.; Chessa, L.; Villa, A.; Lecis, D.; Delia, D.; et al. Ataxia-telangiectasia-mutated dependent phosphorylation of Artemis in response to DNA damage. Cancer Sci. 2005, 96, 134-141. [CrossRef] [PubMed]

148. Lee, B.S.; Gapud, E.J.; Zhang, S.; Dorsett, Y.; Bredemeyer, A.; George, R.; Callen, E.; Daniel, J.A.; Osipovich, O.; Oltz, E.M.; et al. Functional intersection of ATM and DNA-dependent protein kinase catalytic subunit in coding end joining during V(D)J recombination. Mol. Cell. Biol. 2013, 33, 3568-3579. [CrossRef]

149. Leber, R.; Wise, T.W.; Mizuta, R.; Meek, K. XRCC4 gene product is a target for and interacts with the DNA-dependent protein kinase. J. Biol. Chem. 1998, 273, 1794-1801. [CrossRef]

150. Modesti, M.; Hesse, J.; Gellert, M. DNA binding of Xrcc4 protein is associated with V(D)J recombination but not with stimulation of DNA ligase IV activity. EMBO J. 1999, 18, 2008-2018. [CrossRef]

151. Matsumoto, Y.; Suzuki, N.; Namba, N.; Umeda, N.; Ma, X.-J.; Morita, A.; Tomita, M.; Enomoto, A.; Serizawa, S.; Hirano, K.; et al. Cleavage and phosphorylation of XRCC4 protein induced by X-irradiation. FEBS Lett. 2000, 478, 67-71. [CrossRef]

152. Yu, Y.; Wang, W.; Ding, Q.; Ye, R.; Chen, D.; Merkle, D.; Schriemer, D.; Meek, K.; Lees-Miller, S.P. DNA-PK phosphorylation sites in XRCC4 are not required for survival after radiation or for V(D)J recombination. DNA Repair 2003, 2, 1239-1252. [CrossRef]

153. Lee, K.J.; Jovanovic, M.; Udayakumar, D.; Bladen, C.L.; Dynan, W.S. Identification of DNA-PKcs phosphorylation sites in XRCC4 and effects of mutation at these sites on DNA end joining in a cell-free system. DNA Repair 2003, 3, 267-276. [CrossRef]

154. Sharma, M.K.; Imamichi, S.; Fukuchi, M.; Samarth, R.M.; Tomita, M.; Matsumoto, Y. In cellulo phosphorylation of XRCC4 Ser320 by DNA-PK induced by DNA damage. J. Radiat. Res. 2016, 57, 115-120. [CrossRef]

155. Amiri Moghani, A.R.; Sharma, M.K.; Matsumoto, Y. In cellulo phosphorylation of DNA double-strand break repair protein XRCC4 on Ser260 by DNA-PK. J. Radiat. Res. 2018, 59, 700-708. [CrossRef]

156. Normanno, D.; Négrel, A.; de Melo, A.J.; Betzi, S.; Meek, K.; Modesti, M. Mutational phospho-mimicry reveals a regulatory role for the XRCC4 and XLF C-terminal tails in modulating DNA bridging during classical non-homologous end joining. Elife 2017, 6, e22900. [CrossRef]

157. Wanotayan, R.; Fukuchi, M.; Imamichi, S.; Sharma, M.K.; Matsumoto, Y. Asparagine 326 in the extremely C-terminal region of XRCC4 is essential for the cell survival after irradiation. Biochem. Biophys. Res. Commun. 2015, 457, 526-531. [CrossRef] [PubMed] 
158. Yu, Y.; Mahaney, B.L.; Yano, K.; Ye, R.; Fang, S.; Douglas, P.; Chen, D.J.; Lees-Miller, S.P. DNA-PK and ATM phosphorylation sites in XLF/Cernunnos are not required for repair of DNA double strand breaks. DNA Repair 2008, 7, 1680-1692. [CrossRef] [PubMed]

159. Lim, D.S.; Kim, S.T.; Xu, B.; Maser, R.S.; Lin, J.; Petrini, J.H.; Kastan, M.B. ATM phosphorylates p95/nbs1 in an S-phase checkpoint pathway. Nature 2000, 404, 613-617. [CrossRef]

160. Zhao, S.; Weng, Y.C.; Yuan, S.S.; Lin, Y.T.; Hsu, H.C.; Lin, S.C.; Gerbino, E.; Song, M.H.; Zdzienicka, M.Z.; Gatti, R.A.; et al. Functional link between ataxia-telangiectasia and Nijmegen breakage syndrome gene products. Nature 2000, 405, 473-477. [CrossRef] [PubMed]

161. Gatei, M.; Young, D.; Cerosaletti, K.M.; Desai-Mehta, A.; Spring, K.; Kozlov, S.; Lavin, M.F.; Gatti, R.A.; Concannon, P.; Khanna, K. ATM-dependent phosphorylation of nibrin in response to radiation exposure. Nat. Genet. 2000, 25, 115-119. [CrossRef]

162. Cortez, D.; Wang, Y.; Qin, J.; Elledge, S.J. Requirement of ATM-dependent phosphorylation of brca1 in the DNA damage response to double-strand breaks. Science 1999, 286, 1162-1166. [CrossRef]

163. Gatei, M.; Scott, S.P.; Filippovitch, I.; Soronika, N.; Lavin, M.F.; Weber, B. Khanna, K.K. Role for ATM in DNA damage-induced phosphorylation of BRCA1. Cancer Res. 2000, 60, 3299-3304. [PubMed]

164. Burma, S.; Chen, B.P.; Murphy, M.; Kurimasa, A.; Chen, D.J. ATM phosphorylates histone H2AX in response to DNA doublestrand breaks. J. Biol. Chem. 2001, 276, 42462-42467. [CrossRef] [PubMed]

165. Stiff, T.; O’Driscoll, M.; Rief, N.; Iwabuchi, K.; Löbrich, M.; Jeggo, P.A. ATM and DNA-PK function redundantly to phosphorylate H2AX after exposure to ionizing radiation. Cancer Res. 2004, 64, 2390-2396. [CrossRef] [PubMed]

166. Stucki, M.; Clapperton, J.A.; Mohammad, D.; Yaffe, M.B.; Smerdon, S.J.; Jackson, S.P. MDC1 directly binds phosphorylated histone H2AX to regulate cellular responses to DNA double-strand breaks. Cell 2005, 123, 1213-1226. [CrossRef]

167. Matsuoka, S.; Ballif, B.A.; Smogorzewska, A.; McDonald, E.R.; Hurov, K.E.; Luo, J.; Bakalarski, C.E.; Zhao, Z.; Solimini, N.; Lerenthal, Y.; et al. ATM and ATR substrate analysis reveals extensive protein networks responsive to DNA damage. Science 2007, 316, 1160-1166. [CrossRef]

168. Chan, D.W.; Chen, B.P.; Prithivirajsingh, S.; Kurimasa, A.; Story, M.D.; Qin, J.; Chen, D.J. Autophosphorylation of the DNAdependent protein kinase catalytic subunit is required for rejoining of DNA double-strand breaks. Genes Dev. 2002, 16, 2333-2338. [CrossRef] [PubMed]

169. Douglas, P.; Sapkota, G.P.; Morrice, N.; Yu, Y.; Goodarzi, A.A.; Merkle, D.; Meek, K.; Alessi, D.R.; Lees-Miller, S.P. Identification of in vitro and in vivo phosphorylation sites in the catalytic subunit of the DNA-dependent protein kinase. Biochem. J. 2002, 15, 243-251. [CrossRef]

170. Ding, Q.; Reddy, Y.V.R.; Wang, W.; Woods, T.; Douglas, P.; Ramsden, D.A.; Lees-Miller, S.P.; Meek, K. Autophosphorylation of the catalytic subunit of the DNA-dependent protein kinase is required for efficient end processing during DNA double-strand break repair. Mol. Cell. Biol. 2003, 23, 5836-5848. [CrossRef]

171. Chen, B.P.; Chan, D.W.; Kobayashi, J.; Burma, S.; Asaithamby, A.; Morotomi-Yano, K.; Botvinick, E.; Qin, J.; Chen, D.J. Cell cycle dependence of DNA-dependent protein kinase phosphorylation in response to DNA double strand breaks. J. Biol. Chem. 2005, 280, 14709-14715. [CrossRef]

172. Cui, X.; Yu, Y.; Gupta, S.; Cho, Y.M.; Lees-Miller, S.P.; Meek, K. Autophosphorylation of DNA-dependent protein kinase regulates DNA end processing and may also alter double-strand break repair pathway choice. Mol. Cell. Biol. 2005, 25, 10842-10852. [CrossRef] [PubMed]

173. Neal, J.A.; Dang, V.; Douglas, P.; Wold, M.S.; Lees-Miller, S.P.; Meek, K. Inhibition of homologous recombination by DNAdependent protein kinase requires kinase activity, is titratable, and is modulated by autophosphorylation. Mol. Cell. Biol. 2011, 31, 1719-1733. [CrossRef]

174. Neal, J.A.; Sugiman-Marangos, S.; VanderVere-Carozza, P.; Wagner, M.; Turchi, J.; Lees-Miller, S.P. Unraveling the complexities of DNA-dependent protein kinase autophosphorylation. Mol. Cell. Biol. 2014, 34, 2162-2175. [CrossRef] [PubMed]

175. Tonegawa, S. Somatic generation of antibody diversity. Nature 1983, 302, 575-581. [CrossRef] [PubMed]

176. Malu, S.; Malshetty, V.; Francis, D.; Cortes, P. Role of non-homologous end joining in V(D)J recombination. Immunol. Res. 2012, 54, 233-246. [CrossRef]

177. Block, W.D.; Yu, Y.; Merkle, D.; Gifford, J.L.; Ding, Q.; Meek, K.; Lees-Miller, S.P. Autophosphorylation-dependent remodeling of the DNA-dependent protein kinase catalytic subunit regulates ligation of DNA ends. Nucleic Acids Res. 2004, 32, $4351-4357$. [CrossRef]

178. Chen, B.P.; Uematsu, N.; Kobayashi, J.; Lerenthal, Y.; Krempler, A.; Yajima, H.; Löbrich, M.; Shiloh, Y.; Chen, D.J. Ataxia telangiectasia mutated (ATM) is essential for DNA-PKcs phosphorylations at the Thr-2609 cluster upon DNA double strand break. J. Biol. Chem. 2007, 282, 6582-6587. [CrossRef]

179. Reddy, Y.V.; Ding, Q.; Lees-Miller, S.P.; Meek, K.; Ramsden, D.A. Non-homologous end joining requires that the DNA-PK complex undergo an autophosphorylation-dependent rearrangement at DNA ends. J. Biol. Chem. 2004, 279, 39408-39413. [CrossRef]

180. Scott, S.P.; Zhang, N.; Khanna, K.K.; Khromykh, A.; Hobson, K.; Watters, D.; Lavin, M.F. Cloning and expression of the ataxia-telangiectasia gene in baculovirus. Biochem. Biophys. Res. Commun. 1998, 245, 144-148. [CrossRef]

181. Bakkenist, C.J.; Kastan, M.B. DNA damage activates ATM through intermolecular autophosphorylation and dimer dissociation. Nature 2003, 421, 499-506. [CrossRef] [PubMed] 
182. Stiff, T.; Walker, S.A.; Cerosaletti, K.; Goodarzi, A.A.; Petermann, E.; Concannon, P.; O’Driscoll, M.; Jeggo, P.A. ATR-dependent phosphorylation and activation of ATM in response to UV treatment or replication fork stalling. EMBO J. 2006, 25, 5775-5782. [CrossRef]

183. Kozlov, S.V.; Graham, M.E.; Peng, C.; Chen, P.; Robinson, P.J.; Lavin, M.F. Involvement of novel autophosphorylation sites in ATM activation. EMBO J. 2006, 25, 3504-3514. [CrossRef]

184. Kozlov, S.V.; Graham, M.E.; Jakob, B.; Tobias, F.; Kijas, A.W.; Tanuji, M.; Chen, P.; Robinson, P.J.; Taucher-Scholz, G.; Suzuki, K.; et al. Autophosphorylation and ATM activation: Additional sites add to the complexity. J. Biol. Chem. 2011, 286, 9107-9119. [CrossRef]

185. Pellegrini, M.; Celeste, A.; Difilippantonio, S.; Guo, R.; Wang, W.; Feigenbaum, L.; Nussenzweig, A. Autophosphorylation at serine 1987 is dispensable for murine Atm activation in vivo. Nature 2006, 443, 222-225. [CrossRef] [PubMed]

186. Daniel, J.A.; Pellegrini, M.; Lee, J.H.; Paull, T.T.; Feigenbaum, L.; Nussenzweig, A. Multiple autophosphorylation sites are dispensable for murine ATM activation in vivo. J. Cell Biol. 2008, 183, 777-783. [CrossRef]

187. So, S.; Davis, A.J.; Chen, D.J. Autophosphorylation at serine 1981 stabilizes ATM at DNA damage sites. J. Cell Biol. 2009, 187, 977-990. [CrossRef] [PubMed]

188. Zhou, Y.; Lee, J.-H.; Jiang, X.; Crowe, J.L.; Zha, S.; Paull, T.T. Regulation of the DNA damage response by DNA- PKcs inhibitory phosphorylation of ATM. Mol. Cell 2017, 65, 91-104. [CrossRef] [PubMed]

189. Goodwin, J.F.; Knudsen, K.E. Beyond DNA repair: DNA-PK function in cancer. Cancer Discov. 2014, 4, 1126-1139. [CrossRef]

190. Damia, G. Targeting DNA-PK in cancer. Mut. Res. Fund Mol. Mech. Mutagen. 2020, 821, 111692. [CrossRef]

191. Cook, G.P.; Tomlinson, I.M. The human immunoglobulin VH repertoire. Immunol. Today 1995, 16, 237-242. [CrossRef]

192. Schatz, D.G.; Oettinger, M.A.; Baltimore, D. The V(D)J recombination activating gene, RAG-1. Cell 1989, 59, 1035-1048. [CrossRef]

193. Oettinger, M.A.; Schatz, D.G.; Gorka, C.; Baltimore, D. RAG-1 and RAG-2, adjacent genes that synergistically activate V(D)J recombination. Science 1990, 248, 1517-1523. [CrossRef]

194. McBlane, J.F.; van Gent, D.C.; Ramsden, D.A.; Romeo, C.; Cuomo, C.A.; Gellert, M.; Oettinger, M.A. Cleavage at a V(D)J recombination signal requires only RAG1 and RAG2 proteins and occurs in two steps. Cell 1995, 83, 387-395. [CrossRef]

195. Pergola, F.; Zdzienicka, M.Z.; Lieber, M.R. V(D)J recombination in mammalian cell mutants defective in DNA double-strand break repair. Mol. Cell. Biol. 1993, 13, 3464-3471. [CrossRef] [PubMed] 